\title{
OVERTURNED EOCENE - LOWER PLIOCENE ALLUVIAL STRATUM ON THE SOUTHERN COAST OF LAKE BAIKAL AND ITS NEOTECTONIC SIGNIFICANCE
}

\section{A. Al Hamoud $\oplus^{1,2} \bowtie$, S.V. Rasskazov $\oplus^{1,3}$, I.S. Chuvashova $\oplus^{1,3}$, T.F. Tregub $\oplus^{4}$, M.N. Rubtsova ${ }^{3}$, V.L. Kolomiyets ${ }^{5,6}$, R.Ts. Budaev ${ }^{5}$, A. Hassan ${ }^{3,7}$, M.A. Volkov ${ }^{4}$}

\author{
${ }^{1}$ Irkutsk State University, 3 Lenin St, Irkutsk 664011, Russia \\ ${ }^{2}$ Al-Furat University, Deir Ez-Zor, Syria \\ ${ }^{3}$ Institute of the Earth's Crust, Siberian Branch of the Russian Academy of Science, 128 Lermontov St, Irkutsk 664033, \\ Russia \\ ${ }^{4}$ Voronezh State University, 1 University Sq, Voronezh 394018, Russia \\ ${ }^{5}$ Geological Institute, Siberian Branch of the Russian Academy of Science, 6 Sakhyanova St, Ulan-Ude 670047, Buryatian \\ Republic, Russia \\ ${ }^{6}$ Banzarov Buryat State University, 24a Smolin St, Ulan-Ude 670000, Buryatian Republic, Russia \\ ${ }^{7}$ Al-Baath University, Homs, Syria
}

\begin{abstract}
The study is focused on a section of sediments exposed on the right bank of Mishikha River, Russia. These sediments have a wide range of ages, from the Eocene to the Lower Pliocene. The stratigraphic subdivision of the section is based on the lithogeochemical data and X-ray phase analysis of the mineral compositions. The particle-size analysis shows the alluvial origin of the deposits. Their ages are constrained by spore-pollen spectra in three palynozones: I Eocene - Oligocene, II - Early - Middle Miocene (subzone a - Tsuga, Picea in the lower part, and Quercus, Taxodiaceae, Momipites, Carya in the upper part; subzone b - Fagus, Quercus, Tsuga), and III - the Late Miocene - beginning of the Pliocene (subzone v - Ulmus, Juglans, Carya; subzone g - Carya, Alnus). The section shows a combination of normal and overturned sedimentary layers. The tectonic displacement of the block with its flip was accompanied by the entry into contact of the unlithified Pliocene sediments with a rigid bed and the development of a landslide. The lower age limit of deformations is constrained from the youngest (beginning of the Pliocene) spore and pollen spectrum extracted from deformed layers. It is suggested that the overturned layers result from strike-slip deformations of the sediments at the beginning of the late orogenic stage of the Baikal rift development. The regional correlations of the sedimentary strata give grounds to conclude that the Mishikha section is characteristic of alluvial sedimentation that dominated at the eastern end of the Tankhoi tectonic step (Mishikha-Klyuevka paleovalley), in contrast to the Tankhoi block in the central part of the step, wherein a thick Lower Miocene stratum of swampy-oxbow sediments accumulated. The stratons of the Mishikha section correlate with sedimentary units detected by drilling in the Selenga delta at the central part of the South Baikal basin.
\end{abstract}

KEYWORDS: Baikal; Eocene; Oligocene; Miocene; Pliocene; sediments; palynology; lithogeochemistry; tectonic deformations

FUNDING: The study was carried out under the state assignments of the Institute of the Earth's Crust SB RAS (project 0346-2019-0005) with a partial financial support by the Russian Foundation for Basic Research (grant 18-35-00417 mol_a; A. Al Hamud, A. Hassan).

\section{RESEARCH ARTICLE}

Correspondence: Adnan Al Hamoud, hamoudadnan04@gmail.com
Received: February 11, 2020 Revised: September 2, 2020 Accepted: October 14, 2020

FOR CITATION: Al Hamoud A., Rasskazov S.V., Chuvashova I.S., Tregub T.F., Rubtsova M.N., Kolomiyets V.L., Budaev R.Ts., Hassan A., Volkov M.A., 2021. Overturned Eocene - Lower Pliocene alluvial stratum on the southern coast of Lake Baikal and its neotectonic significance. Geodynamics \& Tectonophysics 12 (1), 139-156. doi:10.5800/GT-2021-12-1-0518 


\title{
ОПРОКИНУТАЯ ЭОЦЕН-НИЖНЕПЛИОЦЕНОВАЯ АЛЛЮВИАЛЬНАЯ ТОЛЩА НА ЮЖНОМ БЕРЕГУ ОЗ. БАЙКАЛ И ЕЕ НЕОТЕКТОНИЧЕСКОЕ ЗНАЧЕНИЕ
}

\author{
А. Аль Хамуд $\AA^{1,2}$, С.В. Рассказов ${ }^{1,3}$, И.С. Чувашова ${ }^{1,3}$, Т.Ф. Трегуб ${ }^{4}$, М.Н. Рубцова ${ }^{3}$, \\ В.Л. Коломиец ${ }^{5,6}$, Р.Ц. Будаев ${ }^{5}$, А. Хассан ${ }^{3,7}$, М.А. Волков ${ }^{4}$
}

\author{
${ }^{1}$ Иркутский государственный университет, 664011, Иркутск, ул. Ленина, 3, Россия \\ ${ }^{2}$ Университет Альфурата, Дер-Аль-Зур, Сирия \\ ${ }^{3}$ Институт земной коры СО РАН, 664033, Иркутск, ул. Лермонтова, 128, Россия \\ ${ }^{4}$ Воронежский государственный университет, 394018, Воронеж, Университетская площадь, 1, Россия \\ ${ }^{5}$ Геологический институт СО РАН, 670047, Улан-Удэ, ул. Сахьяновой, 6, Республика Бурятия, Россия \\ ${ }^{6}$ Бурятский государственный университет им. Д. Банзарова, 670000, Улан-Удэ, ул. Смолина, 24 а, Республика \\ Бурятия, Россия \\ ${ }^{7}$ Университет Аль-Баас, Хомс, Сирия
}

\begin{abstract}
АНнОТАЦИЯ. Разрез осадочных отложений широкого (эоцен-нижнеплиоценового) возрастного диапазона вскрыт и изучен на правобережье р. Мишиха. Стратиграфическое расчленение разреза основано на данных литогеохимии и рентгенофазового анализа минерального состава отложений. По результатам гранулометрического анализа сделан вывод об аллювиальном происхождении отложений. Их возраст определен по спорово-пыльцевым спектрам, которые отнесены к трем палинозонам: I - эоцена - олигоцена, II - раннего и среднего миоцена (подзона а - в нижней части Tsuga, Picea, в верхней части Quercus, Taxodiaceae, Momipites, Carya; подзона b - Fagus, Quercus, Tsuga) и III - позднего миоцена - начала плиоцена (подзона v - Ulmus, Juglans, Carya; подзона g - Carya, Alnus). В разрезе установлено сочетание нормального и опрокинутого залегания осадочных слоев. Тектоническое смещение блока с его переворотом сопровождалось вхождением в контакт нелитифицированных плиоценовых осадков с жесткой подложкой и развитием оползня. Нижний предельный возраст деформаций определен по наиболее молодому (начало плиоцена) спорово-пыльцевому спектру, полученному в деформированных слоях. Предполагается, что в опрокинутом залегании реализованы присдвиговые деформации отложений в начале позднеорогенного этапа развития Байкальского рифта. Из региональных корреляций толщ сделан вывод о том, что Мишихинский разрез характеризует аллювиальное осадконакопление, которое доминировало на восточном окончании Танхойской тектонической ступени, в Мишихинско-Клюевской палеодолине, в отличие от Танхойского блока центральной части ступени, в котором обнажена мощная нижнемиоценовая толща болотно-старичной фации. Стратоны Мишихинского разреза коррелируются со стратонами, вскрытыми скважинами в дельте p. Селенги в центральной части Южно-Байкальской впадины.
\end{abstract}

КЛЮчЕВЫЕ СЛОВА: Байкал; эоцен; олигоцен; миоцен; плиоцен; осадочные отложения; палинология; литогеохимия; тектонические деформации

ФИНАНСИРОВАНИЕ: Работы выполнены в рамках госзаданий по проекту Института земной коры № 03462019-0005 с частичной поддержкой грантом РФФИ № 18-35-00417 мол_а (А. Аль Хамуд, А. Хассан).

\section{1. ВВЕДЕНИЕ}

В южном борту Южно-Байкальской впадины находится Танхойская тектоническая ступень, которая отставала в своем развитии от поднятия хр. Хамар-Дабан и погружения дна озерной котловины. Ширина ступени - до 8 км, протяженность - 80 км. На поверхности ступени покоятся кайнозойские отложения, которые были отнесены к осадочному наполнению впадин байкальского типа, включающему угленосную, охристую и песчаную свиты [Logatchev, 1958]. В легенде к государственным геологическим картам первые два стратиграфических подразделения получили географические названия по стратотипам тектонической ступени как танхойская и аносовская свиты (для песчаной свиты географическое название в легенде не определено). В качестве голостратотипа танхойской свиты исследовался наиболее представительный, по палеонтологической обоснованности, разрез танхойской свиты р. Половинка, в котором были вскрыты отложения не древнее миоценовых [Rasskazov et al., 2014]. Кроме того, в стратотипической местности свит были дополнительно выделены новые свиты неогена: осиновская и шанхаихинская [Mats, 1985; Mats et al., 2001].

На Танхойской тектонической ступени долгое время обсуждается вопрос о ее наиболее древних отложениях. Предполагалось, что их возраст не должен быть древнее среднего олигоцена [Logatchev, 1974]. Олигоценовый возраст был определен по составу спор и пыльцы в «контактной пачке синих глин», залегающей в основании разреза, впервые отмеченной Ю.М. Шейнманном в 1931 г. [Mazilov et al., 1972]. В связи с ограниченным распространением олигоценовых отложений во впадинах Байкальской рифтовой зоны и сопредельных районов Западного Забайкалья «контактная пачка синих 
глин» левобережья р. Осиновка-Танхойская рассматривалась в качестве дотанхойского стратона [Rasskazov et al., 2014]. Местонахождение «синих глин» в разрезе р. Половинка [Mats, 2015] было указано ошибочно. Фактически все наблюдения «контактной пачки» ограничивались их единственным местонахождением на левобережье р. Осиновка-Танхойская [Mazilov et al., 1972; и др.].

В работе [Mashchuk, Akulov, 2012] обращалось внимание на залегание «синих глин» этого местонахождения на коре выветривания, возраст которой обозначался как эоценовый по аналогии с одной из K-Ar датировок, полученных М.М. Аракелянц для коры выветривания на противоположном берегу Байкала. Такое предположение не сопровождалось какой-либо дополнительной аргументацией возраста. Между тем в Прибайкалье проявился не один, а, по меньшей мере, три эпизода выравнивания рельефа, сопровождавшегося глубоким химическим выветриванием: 1) предъюрский, 2) рубежа мела - палеоцена и 3) рубежа палеоцена - эоцена [Logatchev, 1974]. Оценка возраста второго (наиболее яр-

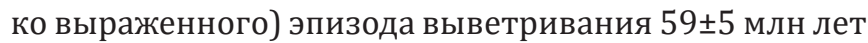
была получена для коры выветривания в Предсаянье с использованием специальной методики - ступенчатого нагрева крупных (0.5-2.0 см) кристаллов вермикулита с расчетом фракции радиогенного ${ }^{40} \mathrm{Ar}$, накопившегося в закрытой K-Ar-изотопной системе [Logatchev et al., 2002].

Новая информация по нижней части разреза кайнозойской осадочной толщи появилась благодаря вскрышным работам на федеральной трассе Иркутск - Улан-Удэ, проводившимся в 2014 г. в восточной части Танхойской тектонической ступени. На правобережье р. Мишиха под слоем верхнеолигоценовых «синих глин» был вскрыт слой аллювиальных охристых отложений, содержащих спорово-пыльцевой спектр позднего эоцена. Этот слой был выявлен в расчистке южного борта дороги, обнажившей субгоргизонтально залегающую толщу. Выше слоя «синих глин» было выделено еще четыре стратона: нижнемиоценовый (нижнетанхойский), преимущественно алевритовый, с прослоями бурого угля; средневерхнемиоценовый (осиновский), без углистых прослоев; верхнемиоценовый (верхнетанхойский), песчано-алевритовый, с фрагментами «синих глин», а также два четвертичных (перекрывающих), песчаный и валунно-галечный [Al Hamoud et al., 2019]. Находка эоценовых отложений и широкий возрастной диапазон стратонов южной расчистки делают Мишихинский разрез опорным для Танхойской тектонической ступени.

В настоящей работе характеризуются слои в расчистке северного борта дороги Мишихинского разреза, в которой осадочная толща наклонена. Более того, вследствие деформаций толщи в восточной части расчистки древние слои частично оказались выше молодых. Вскрыт контакт эоцен-верхнеолигоценовой толщи с нормальным стратиграфическим залеганием и эоцен-нижнеплиоценовой толщи с опрокинутым залеганием.
Трещины и зеркала скольжения в слоях осадочных отложений нередко используются для реконструкций поля тектонических напряжений в разломах верхней части коры. Опрокинутое залегание может быть следствием надвиговых или сдвиговых деформаций. Между тем слои осадочных отложений озерного бассейна тектонического происхождения часто вовлекаются в оползневые движения под действием гравитационных сил. Преувеличение роли эндогенных или экзогенных факторов деформаций осадочного материала может привести к ошибочным заключениям, во избежание которых необходимо всестороннее изучение осадочных пород в свете неотектонической эволюции территории.

Приводятся результаты литолого-стратиграфических и палинологических исследований осадочных отложений северной расчистки Мишихинского опорного разреза с целью обозначить роль не только эндогенного (тектонического) фактора в опрокидывании слоев, но и экзогенного (оползневого), проявившегося в контакте слоев с нормальным и опрокинутым залеганием.

\section{2. ОБЪЕКТ И МЕТОДЫ ИССЛЕДОВАНИЙ}

Северная расчистка разреза расположена в 1100 м от р. Мишиха (рис. 1). Протяженность непрерывно обнаженного участка составляет около 700 м. Все вскрытые слои наклонены вдоль дороги к востоку под углом 15-20․ Субгоргизонтально залегающая толща изученной ранее южной расчистки совмещена с деформированными слоями северной расчистки по разлому, проходящему вдоль дорожного полотна.

Гранулометрический анализ отложений выполнен с использованием комплекса сит, предназначенного для определения зернового состава отдельных фракций щебня (гравия) по ГОСТ 8269.0-97, песка и глинистых частиц по ГОСТ 8735-88. Минеральный состав отложений определен рентгенофазовым анализом методом порошковой дифракции на рентгеновском дифрактометре ДРОН-3.0. Результаты полуколичественного анализа порошковых образцов использовались для расчета минеральных фаз по корундовым числам (RIR) [Hubbard, Snyder, 1988]. Глинистые минералы идентифицированы в ориентированных образцах тонкой фракции, осажденной на стеклянной подложке в воздушно-сухом и насыщенном этиленгликолем состоянии, а также после прокаливания при температуpe $550{ }^{\circ} \mathrm{C}$ в течение трех часов [Brown, 1965].

Определения петрогенных оксидов в породах выполнены в ИЗК СО РАН методом «мокрого химического анализа». Просушиванием образцов при температуре $105{ }^{\circ} \mathrm{C}$ удалялась гигроскопическая вода $\left(\mathrm{H}_{2} \mathrm{O}^{-}\right)$и прокаливанием при температуре $950{ }^{\circ} \mathrm{C}$ - другие летучие компоненты (потери при прокаливании, ППП). Высокотемпературным прогревом из осадочных пород извлекалась конституционная вода минералов (в том числе глинистых) и отжигался детритовый органический материал. Спорово-пыльцевые спектры дочетвертичных 
отложений разреза определялись в биостратиграфической лаборатории Воронежского госуниверситета. Для обработки данных палинологического анализа и химического состава пород применен факторный анализ по программе Statistica 12 методом главных компонент без ротации.

\section{3. СТРОЕНИЕ РАЗРЕЗА}

В северной расчистке различаются наклоненные толщи западной и восточной части и перекрывающая галечниковая пачка с субгоризонтальным залеганием (рис. 2). В западной части представлена мишихинская толща (ms), в восточной - мишихинская и танхойская толщи (соответственно ms и tn). Общая протяженность расчистки около 700 м, большая часть приходится на восточную опрокинутую часть.

\section{1. Западная часть расчистки}

Здесь в нормальной стратиграфической последовательности находятся пачки 13 (ms) - 43 (ms) (с запада на восток).

Пачка 13 (ms) сложена переслаивающимися аргиллитом и песчаником. Аргиллит темно-серого цвета, вязкий во влажном состоянии. Песчаник крупнозернистый, интенсивно обохренный, с примесью гравия и редкими включениями гальки бурого цвета. Мощность пачки до 3.3 м.

Пачка 23 (ms) представлена в нижней части чередующимися слоями песчаника, темно-коричневого и серого, среднекрупнозернистого, плохо промытого, слабообохренного и слабосцементированного. Наблюдаются переходы к разнозернистым слоям до гравелистых, косослоистых. В верхней части преобладает алевролит с переходом к алевропесчанику. Мощность пачки до 4 м.

Пачка 33 (ms) представлена песчаником, тонкозернистым, светло-коричневым, слабосцементированным, с маломощными (до 0.7 см) прослоями серых аргиллитов. Нижний контакт четко выражен. В основании пачки наблюдаются скопления песчаного и гравийного материала. Мощность до 2.5 м.

Пачка 4 з (ms) состоит преимущественно из светло-серого алевролита и песчаника тонко- и мелкозернистого, светло-коричневого, обохренного в приконтактовой зоне, переслаивающегося с алевролитом светло-коричневым. Пачка венчается слоем песчаника мелкозернистого, светло-коричневого, мощностью 0.8 м. Мощность пачки $5.8 \mathrm{M}$.

Общая видимая мощность мишихинской толщи в западной части расчистки составляет 15.6 м.

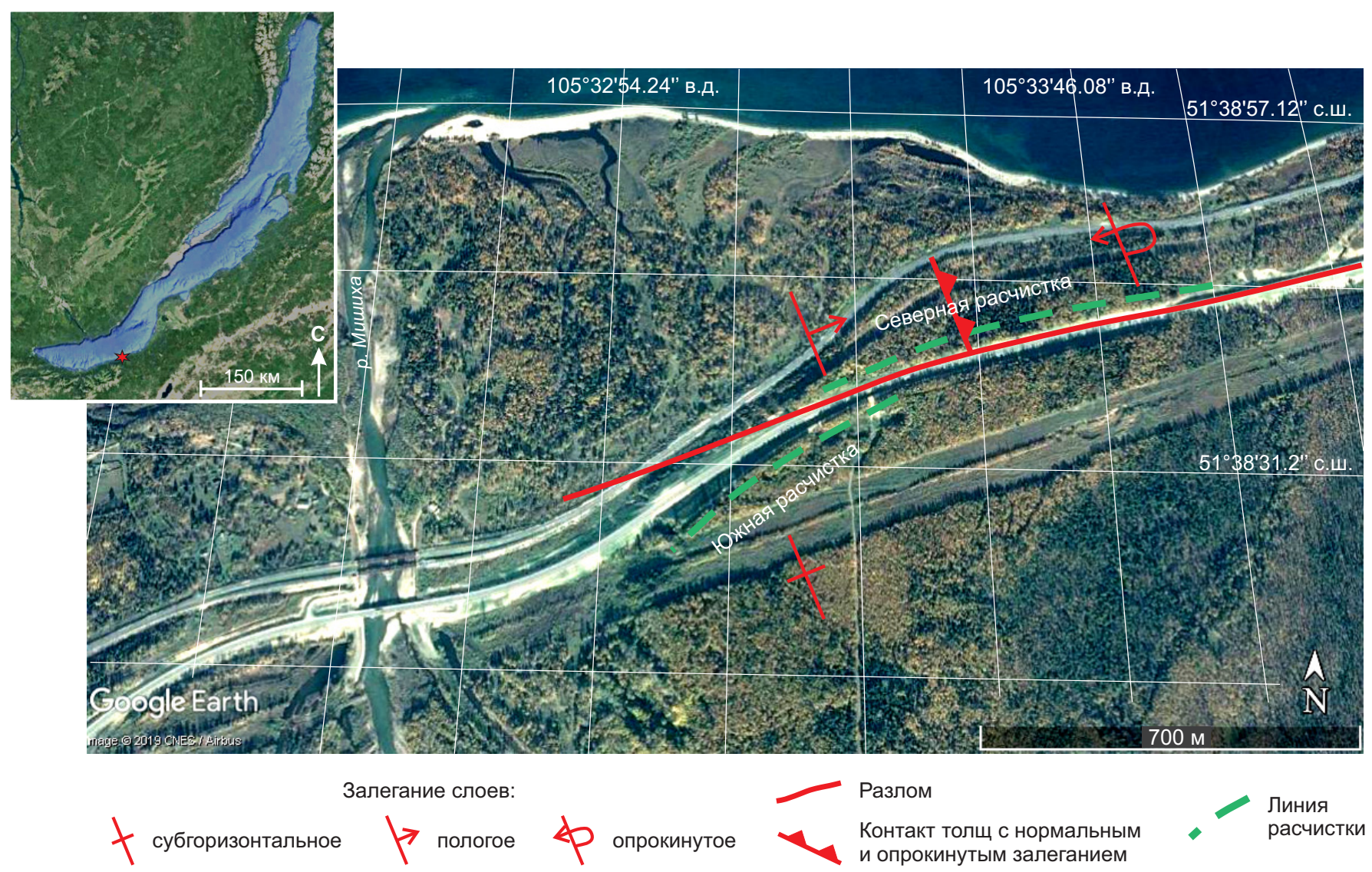

Рис. 1. Местоположение северной и южной расчистки Мишихинского опорного разреза на шоссейной дороге Иркутск -Улан-Удэ. Красная звездочка на врезке обозначает положение устья р. Мишиха.

Fig. 1. Locations of the northern and southern outcrops at the Irkutsk - Ulan-Ude highway, Mishikha section. Inset: red asterisk Mishikha River estuary. 


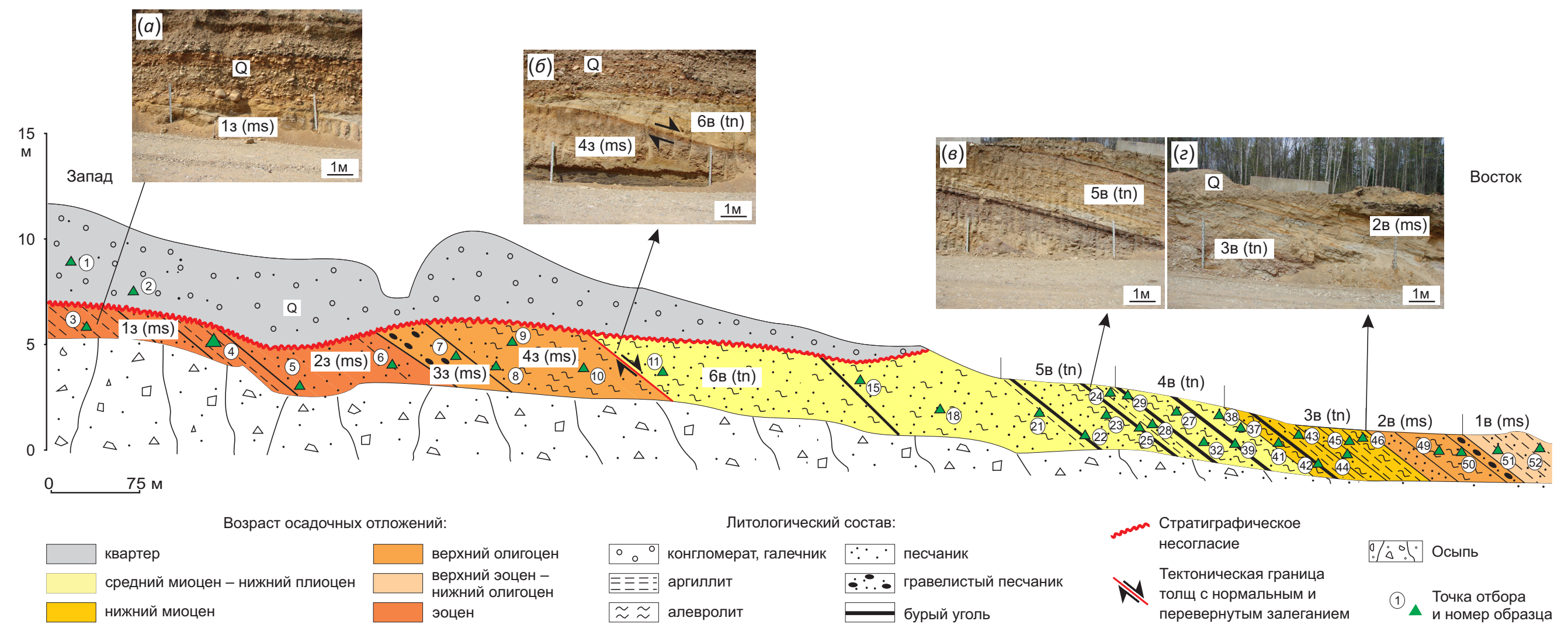

Рис. 2. Схема опробования осадочных толщ в северной расчистке Мишихинского опорного разреза.

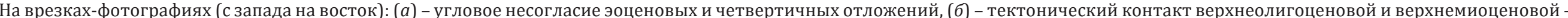

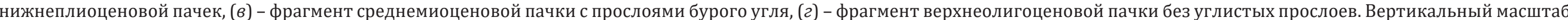
превышает горизонтальный в 18 раз, что влечет за собой кажущееся увеличение наклона слоев.

Fig. 2. Sampling scheme of the sedimentary sequences in the northern outcrop, Mishikha section.

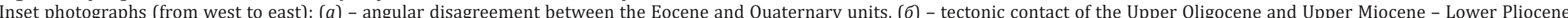

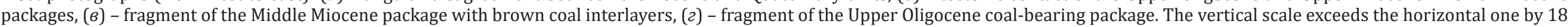
times, which why the layers' slope looks increased in the scheme. 


\section{2. Восточная часть расчистки}

В восточной части расчистки в стратиграфической последовательности (в опрокинутом залегании с востока на запад) обозначаются шесть пачек, две из которых относятся к мишихинской толще (1в (ms) - 2в (ms)) и четыре - к танхойской свите (3в (tn) - 6в (tn)).

Пачка 1в (ms) сложена аргиллитом темно-серым, в верхней части - песчаником крупнозернистым, коричневым и серым, с примесью гравия. Видимая мощность пачки до 1.5 м.

Пачка 2в (ms) образована переслаиванием алевролита темно-серого и песчаника среднекрупнозернистого до гравийного, коричневато-серого. Отмечен небольшой прослой аргиллита. Мощность пачки до 2 м.

Пачка 3в (tn) начинается переслаиванием аргиллита темно-серого и песчаника светло-коричневого, мелко- и среднезернистого, слабосцементированного и завершается слоем алевролита темно-серого, мелкозернистого с песчаником мелкозернистым светло-коричневым. Наблюдается прослой угля темно-бурого, пластинчатого мощностью около 15 см. Мощность пачки до 3.3 м.

Пачка 4в (tn) дает переслаивание алевролита темно-серого и песчаника мелкозернистого, светло-коричневого до бурого, слабосцементированного. Встречен прослой аргиллита, гумусированного, мощностью 5-7 см. В нижней и верхней части пачки находятся прослои бурого угля мощностью до 20 см. Мощность пачки до $2.4 \mathrm{M}$.

Пачка 5в (tn) в нижней части характеризуется переслаиванием аргиллита, плотного, темно-серого, и песчаника крупнозернистого, слабосцементированного, светло-серого с примесью гравия. В верхней части наблюдается переслаивание алевролита, плотного, темно-серого, зеленовато-серого, и песчаника мелкозернистого, коричневого. Присутствуют прослои бурого угля мощностью до 30 см. Мощность пачки до 5 м.

Пачка 6в (tn) образована многократной перемежаемостью песчаника и алевролита. Песчаник тонкозернистый, темно-серый. Алевролит светло-коричневый. В средней части пачки встречены прослои гравия и угля. Уголь темно-коричневый до черного, раскалывается на пластинки. Мощность пачки до 6.5 м.

Вскрытая мощность мишихинской толщи в восточной части расчистки составляет 3.5 м, танхойской свиты - 17.2 м. Мощность мишихинского стратона в опрокинутой восточной части обнажения сокращается по отношению к его мощности в нормально залегающей западной части приблизительно в четыре раза.

\section{3. Тектонический контакт толщ с нормальным и опрокинутым залеганием}

На границе толщ западной и восточной части расчистки темно-коричневый алевропесчаник пачки 43 (ms) резко сменяется светло-коричневым алевролитом пачки 6в (tn). В плотно сцементированном алевропесчанике пачки 43 (ms) развита мелкая комковатость (катаклаз). В алевролите пачки 6в (tn) трещиноватость отсутствует. В слое светло-коричневого алевролита параллельно контакту протягиваются тонкие (до 3 см) слои и уплощенные линзы темно-серого песчаника. Ближе к контакту слои становятся нечеткими и сменяются однородным алевролитом.

Эти наблюдения свидетельствуют о смещении толщи, расположенной выше контакта, по слою, который находился в пластичном (жидком) состоянии на хрупкой подложке.

\section{4. Перекрывающие четвертичные отложения}

Перекрывающий покров составляет мелкий галечник с крупнозернистым песчаным наполнителем от коричневого до черного цвета. Отложения имеют субгоризонтальную слоистость, субпараллельную поверхности размыва. В нижней части толщи наблюдаются западины и встречаются валуны размером до 20 см. Мощность галечникового покрова во вскрытой части разреза достигает 4 м.

\section{4. ПАЛИНОЛОГИЧЕСКОЕ ОБОСНОВАНИЕ ВОЗРАСТА ОТЛОЖЕНИЙ}

На спорово-пыльцевой диаграмме осадочных отложений северной расчистки (рис. 3) выделяются три палинозоны.

Палинозона I выделяется по палиноспектрам пяти образцов: $3,4,52,49,10$. Палиноспектры образцов 3 и 4 из пачки 13 (ms) западной части расчистки обогащены пыльцой покрытосеменных (68.7-78.8 \%), обеднены пыльцой голосеменных (13.8-24.1\%) и травянистых растений (1.3-1.5\%). Содержание спор - 5.9 \%. В составе пыльцы голосеменных пород преобладают Тахоdiaceae и Sequoia. Богатый родовой и видовой состав пыльцы покрытосеменных древесных пород, а также наличие таких формальных родов, как Triatriopollenites, Triporopollenites и вида Ulmoideipites planeraeformis, позволяют коррелировать данную часть разреза с комплексами из отложений стратотипических разрезов, относящихся к переходу от нижнего эоцена (обр. 3) к среднему эоцену (обр. 4).

Палиноспектр 52 из пачки 1в (ms) восточной части расчистки характеризуется преобладанием пыльцы покрытосеменных (54.8 \%) и голосеменных (34.1\%) растений. Сумма спор увеличивается до $11.1 \%$. Травы отсутствуют. Так же, как в палиноспектрах образцов 3 и 4, в палиноспектре обр. 52 преобладает пыльца голосеменных пород Taxodiaceae и Sequoia. В этом палиноспектре, кроме разнообразия хвойных пород, среди которых отмечено заметное участие пыльцы таких родов, как Keteleria и Podocarpus, возрастает роль рода Tsuga, резко снижается значение вида Ulmoideipites planeraeformis и начинает преобладать пыльца рода Juglans, что характерно для отложений верхнего эоцена - нижнего олигоцена.

Палиноспектр 10 из пачки 43 (ms) западной части разреза сопоставляется с палиноспектром 49 из пачки 2в (ms) восточной части разреза. В составе обоих палиноспектров определены: пыльца покрытосеменных 
(46.9-47.1\%), голосеменных (39.8-42.2 \%) пород, споры (7.2-11.4 \%), пыльца трав (1.9-2.4 \%). Спектры образцов 10 и 49 характеризуются приблизительно равным содержанием пыльцы голосеменных и покрытосеменных пород. Беднее становится состав пыльцы древесных растений, и преобладает пыльца семейства Juglondaceae, в составе которого заметную роль играет род Carya. Небольшое различие вносит наличие в обр. 10 заметного количества пыльцы рода Comptonia, что при общем позднеолигоценовом накоплении обеих пачек может свидетельствовать о более раннем формировании пачки 43 (ms) и более позднем - пачки 2в (ms).

Палинозона II включает палиноспектры образцов 46 и 41 из пачки 3в (tn) и обр. 24 из пачки 5в (tn) восточной части расчистки. В указанных образцах, так же как в образцах I палинозоны, наблюдается разнообразие на родовом и видовом уровне состава пыльцы покрытосеменных и голосеменных пород. Палинозона II выделена по максимальному значению с большим видовым разнообразием пыльцы родов: Tsuga, Taxodium sp. и Sequoia. В отличие от первой палинозоны, во второй возрастает количество спор.

В этой зоне выделяются две подзоны: a и b. В подзоне а (обр. 46 и 41) содержится пыльца покрытосеменных (49.5-49.6 \%) и голосеменных (32.1-43.5 \%) пород. Споры составляют от 6.9 до 17.9 \%. В группе травянистых встречается только одно семейство (Onograceae, 0.5 \%). В нижней части подзоны среди голосеменных растений доминирует пыльца Tsuga и рода Picea, а в верхней части - в основном пыльца родов покрытосеменных Quercus, Taxodium, Momipites и Carya. В подзоне отмечается возрастание роли пыльцы покрытосеменных пород, но ее состав практически не меняется. Заметное количество пыльцы рода Momipites указывает
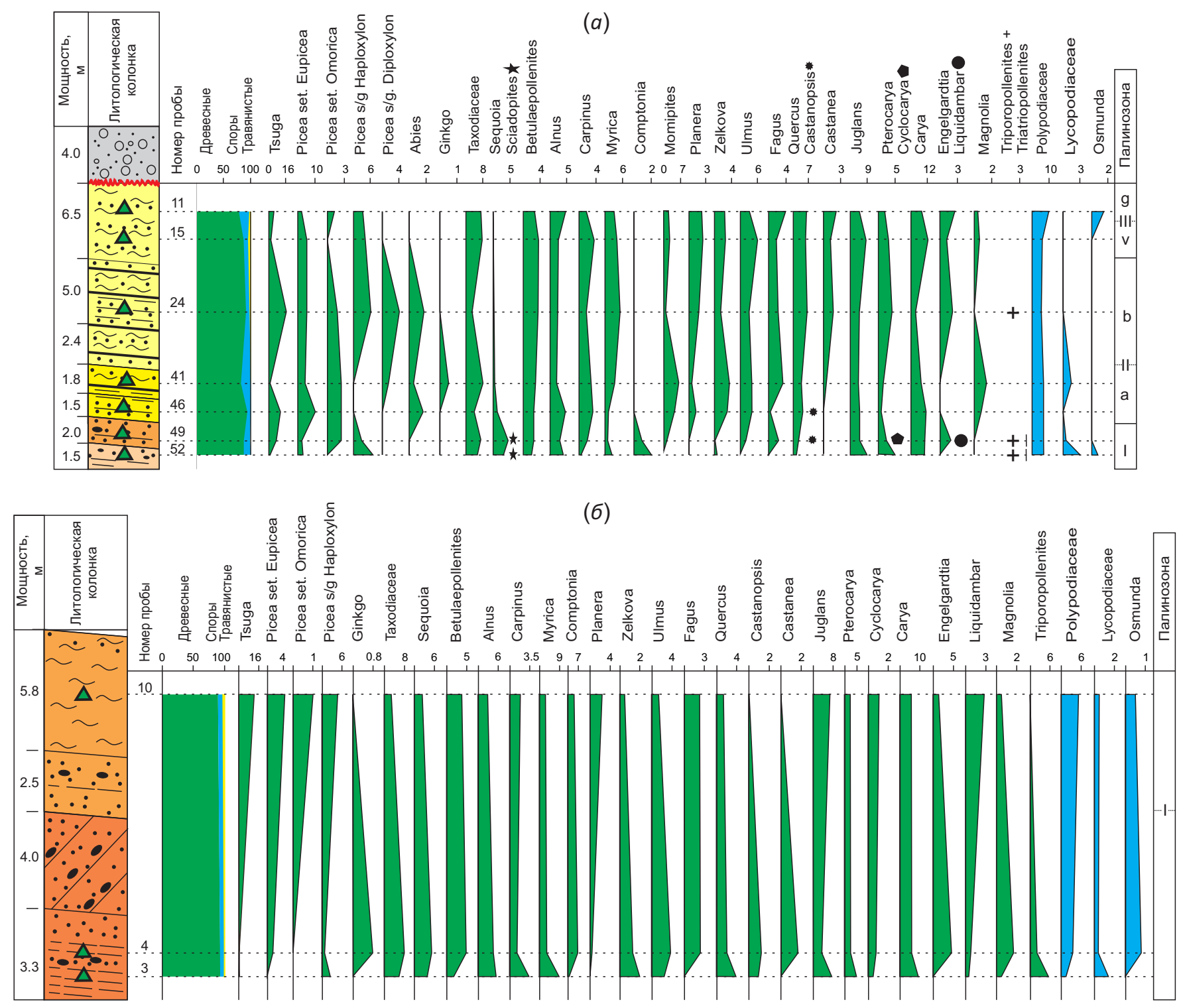

Рис. 3. Спорово-пыльцевая диаграмма отложений северной расчистки Мишихинского разреза: (a) - восточная часть, (б) западная часть.

Fig. 3. Spore-pollen diagram of the sediments from the northern outcrop, Mishikha section: (a) - eastern part, (б) - western part. 
на нижнемиоценовый возраст палиноспектров подзоны а. В подзоне b (обр. 24) в составе покрытосеменных пород преобладает пыльца родов Fagus и Quercus, в составе хвойных пород - Tsuga (4 вида). В связи с этим возраст вмещающих отложений, вероятнее всего, соответствует среднему миоцену.

Палинозона III обозначена по палиноспектрам образцов 15 и 11 из пачки 6в (tn). В этих палиноспектрах преобладает пыльца покрытосеменных пород (53.1$62.9 \%)$. Пыльца голосеменных пород составляет 23.5$24.5 \%$. Споры занимают относительно большой объем в интервале от 8.3 до 19.3 \%, а пыльца травянистых растений составляет от 3.1 до 5.3 \%. В целом III палинозона характеризуется обеднением спор и пыльцы как в видовом, так и в родовом составе. Но в ней встречается значительно большее количество пыльцы травянистых растений. В отличие от II палинозоны, споры представлены в меньшем количестве.

По вариациям содержания отдельных элементов в составе палиноспектров выделяются две подзоны: $v$ и g [Bolotnikova, 1979; Tomskaya, 1981]. В подзоне v (обр. 15) на фоне снижения роли пыльцы голосеменных пород резко преобладает пыльца трех родов (Ulmus, Juglans, Carya). Присутствует пыльца Quercus. Эти формы характерны для отложений верхнего миоцена. В подзоне g (обр. 11) господствует пыльца покрытосеменных деревьев с максимальным содержанием пыльцы Carya, Quercus, Ulmus с заметным участием пыльцы рода Fagus. Среди голосеменных пород доминирует пыльца Тахоdiaceae, Pinus и Tsuga. Эта подзона хорошо коррелируется с фазами раннего плиоцена.

В целом осадочные отложения всех пачек западной части расчистки и пачек 1в-2в (ms) восточной части расчистки датируются по палиноспектрам I палинозоны эоценом - олигоценом, отложения пачек 3в-5в (tn) восточной части расчистки по палиноспектрам II палинозоны - нижним - средним миоценом и отложения пачки 6в (tn) восточной части расчистки по палиноспектрам III палинозоны - началом нижнего плиоцена.

На рис. 4 представлены результаты факторного анализа палиноспектров в координатах первого и третьего фактора, составляющих соответственно 22.4 и $13.8 \%$ изменчивости всей совокупности образцов.

На диаграмме рис. 4, б, выделилась группа векторов пыльцы из 14 пород широколиственных растений отрицательными значениями фактора 1 при отрицательных значениях фактора 3 в квадранте III. На диаграмме рис. 4, б, в этом же квадранте диаграммы находятся векторы эоценовых образцов. Растительное сообщество обозначает развитие широколиственных лесов богатого видового состава с заметным участием тропических элементов - Liquidambar, Platycarya, Pterocarya. Отмечены дубы и представитель рода Ulmoidites, характерные для отложений эоцена, а также элементы искусственной классификации - Triatriopollenites, представителя палеоценовой флоры. Преобладание в составе хвойных болотного кипариса и секвойи указывает на широкое развитие озер и заболоченных территорий.
Нижний ярус растительности развит слабо. Климат был близок к тропическому, но наличие листопадных пород указывает на заметные перепады летних и зимних температур. Подобный состав лесов описан для отложений позднего палеоцена на территории Северо-Китайской флористической провинции [Bolotnikova, 1979].

Пыльцевые векторы, смещенные в положительную область фактора 3 (квадрант II), соответствуют векторам образцов 52, 10 и 49. Обр. 52 соответствует постепенному усилению аридизации на поздних стадиях эоцена, которое привело к резкому расширению ареала дубово-буковой составляющей в широколиственных лесах с доминировавшими гикориево-ореховыми зарослями и небольшим участием тропических вечнозеленых пород. Описанный состав растительности субтропического типа свидетельствует о теплом климате с пониженной влажностью. Значительное участие в составе хвойных пород болотного кипариса и секвойи в образцах 10 и 49 говорит о существовании в позднем олигоцене обширных заболоченных территорий. В речных долинах были широко развиты ореховые леса с участием лапины, бука, дуба, граба, ликвидамбара, восковника, с подлеском из комптонии. В горном районе с субтропическим климатом развиты обширные заболоченные территории с возрастанием аридизации. Горообразующие тектонические процессы имели место, скорее всего, до среднего олигоцена.

Палиноспектры образцов палинозоны II $(41,46,24)$ смещаются в квадранты IV и I. Палиноспектры образцов 46 и 41 подзоны а характеризуются примерно одинаковым содержанием пыльцы голосеменных и покрытосеменных пород. В составе палиноспектра обр. 41 более разнообразно представлена пыльца покрытосеменных растений. Преобладают Momipites, Carya, Juglondaceae, Quercus и Ulmus. Присутствует пыльца голосеменных растений в основном трех видов: Tsuga, Picea и Taxodium. Климат достаточно теплый и относительно сухой. Обр. 24 подзоны b дает резко положительное значение фактора 3. Несмотря на вариации встречаемости основных составляющих, для этой подзоны характерна общая составляющая - присутствие в составе темнохвойных лесов тсуги. В целом, эта подзона характеризуется умеренно теплым климатом, постепенно переходящим к умеренно прохладному, хотя и продолжают встречаться формы термофильных видов широколиственных пород.

Палиноспектры образцов палинозоны III $(15,11)$, имеющие положительные значения первого и третьего фактора, содержат пыльцу лиственных, доля которых увеличивается до 62.9 \%. Палинозона характеризуется разнообразной пыльцой и спорами теплого климата.

В ходе смены растительности среднего и позднего кайнозоя обособляются два временных интервала изменения климата. Первый (мишихинское время) обозначает тренд от тропического климата в эоцене к субтропическому в олигоцене. Второй (конец мишихинского времени и танхойское время) дает ортогональное 
(a)

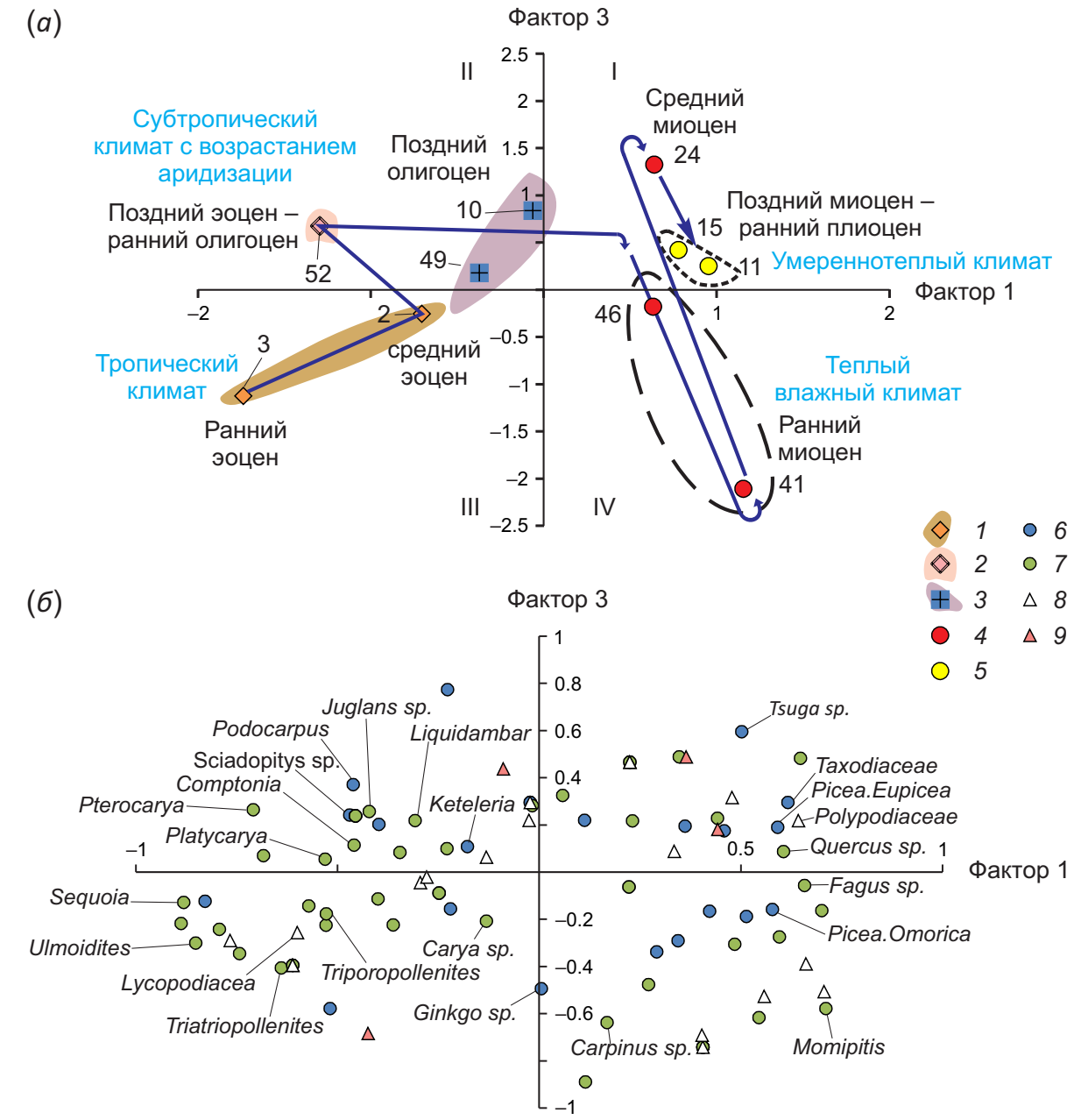

(б)

Рис. 4. Факторные диаграммы спорово-пыльцевых спектров осадочных отложений.

(a) - диаграмма векторов образцов: 1-3 - стратоны мишихинской толщи: эоценовый (1), верхнеэоценовый - нижнеолигоценовый (2), верхнеолигоценовый (3); 4-5 - то же, танхойской свиты: нижне- и среднемиоценовый (4), верхнемиоценовый - нижнеплиоценовый (5); (б) - диаграмма векторов переменных: 6-9 - голосеменные породы (6), покрытосеменные породы (7), споры (8), травы (9).

Fig. 4. Factor diagrams of the spore-pollen spectra.

(a) - diagram of sample vectors: 1-3 - units of the Mishikha stratum: Eocene (1), Upper Eocene - Lower Oligocene (2), Upper Oligocene (3); 4-5 - units of the Tankhoi Formation: Lower - Middle Miocene (4), Upper Miocene - Lower Pliocene (5); (6) - diagram of vectors for variables: 6-9 - gymnosperms (6), angiosperms (7), spores (8), herbs (9).

направление к умеренно теплому и сухому климату с растительностью, обозначившей похолодание, начавшееся в самом конце олигоцена в рамках палинозоны I и продолжавшееся в палинозонах II и III.

\section{5. ГРАНУЛОМЕТРИЧЕСКИЙ АНАЛИЗ ОТЛОЖЕНИЙ}

В исследование гранулометрического состава вовлечен материал всех наклоненных слоев северной расчистки, за исключением алевролитового слоя пачки 43 (ms), в котором видимая обломочная фракция не идентифицируется (рис. 5). Ископаемые диатомовые водоросли отсутствуют во всех слоях, включая алевролитовую пачку 43 (ms), что свидетельствует об отсутствии типичных отложений застойных лимнических бассейнов. Рассматриваемые осадочные отложения имели аллювиальное происхождение. Даже самые тонкие фракции отлагались в водоемах с проточным режимом.
Палеопотамологические условия аллювиального осадконакопления реконструируются с использованием гранулометрического состава осадков по формулам, приведенным в работе [Kolomiets, 1998].

По всему разрезу преобладают аллювиальные песчаники $(0.8<v<2.0)$. Обломочные частицы песчаников имеют различные размеры - от алевритового и алевритово-мелкозернистого ( $\mathrm{x}=0.34-0.38$ мм) до крупносреднезернистого ( $\mathrm{x}=0.57-0.60$ мм), мелко- и среднекрупнозернистого ( $\mathrm{x}=0.72-0.85$ мм), крупнозернистого ( $\mathrm{x}=$ 0.90-1.06 мм), грубокрупнозернистого ( $\mathrm{x}=1.17-1.34$ мм) псаммитового и галечно-гравийно-песчаного ( $\mathrm{x}=1.65-$ 1.84 мм). Имеются общие тенденции изменения численных значений основных статистических и гидродинамических параметров среды седиментации (табл. 1). Наиболее грубообломочные фации характеризуют низ, середину и верх эоценовой части разреза (рис. 6). 
Самые мелкие песчаные разновидности осадков за счет содержания небольших примесей более крупных обломочных частиц (до 3 \%) имеют недостаточную сортировку ( $\sigma=0.42-0.64)$ и положительную асимметрию, указывающую на умеренную энергию осадконакопления при сохранении относительной тектонической стабильности ( $\tau=12.44-19.86)$. Для палеоводотоков, служивших средой аккумуляции осадочного материала, был характерен спокойный гидрологический режим. Они относятся к равнинному $(\mathrm{Fr}<0.1)$ типу натуральных, блуждающих, незасоренных русел с площадью водосбора >100 км² и свободным течением воды.

Аллювиальные отложения, переходные к озерным $(0.4<v<0.8)$, представлены песчаными алевритами $(\mathrm{x}=$ 0.07-0.09 мм), алевропесчаниками ( $\mathrm{x}=0.13-0.15$ мм) и алевритово-мелкозернистыми разностями отложений ( $\mathrm{x}=0.17-0.20$ мм) с совершенной и хорошей сортировкой $(\sigma=0.06-0.15)$. Эти отложения асимметричны с доминантным модальным сдвигом в сторону крупных частиц $(\alpha>1)$. Резко положительный эксцесс свидетельствует о спокойном тектоническом состоянии территории. Аккумуляция происходила в мелководном стационарном проточном водоеме (глубины 0.7-1.8 м). Его притоки речного облика имели малоподвижные ( $\phi$-критерий $<100$ единиц) русла равнинного типа (Fr= 0.01-0.03) в естественных, благоприятных условиях состояния ложа со свободным течением воды (n>44) с
Таблица 1. Результаты статистической обработки данных минерального состава отложений

Table 1. Results of statistical processing of the mineral compositions of the sediments.

\begin{tabular}{cccc}
\hline \multirow{2}{*}{$\begin{array}{c}\text { Статисти- } \\
\text { ческие } \\
\text { параметры }\end{array}$} & \multicolumn{3}{c}{ Содержание минералов, \% } \\
\cline { 2 - 4 } & Кварц & $\begin{array}{c}\text { Полевые } \\
\text { шпаты }\end{array}$ & $\begin{array}{c}\text { Глинистые } \\
\text { минералы }\end{array}$ \\
\hline \multicolumn{4}{c}{ Эоценовые отложения $(\mathrm{n}=4)$} \\
\hline $\mathrm{X}_{\text {ср. }}$ & 31.25 & 51.25 & 18.75 \\
$\sigma$ & 3.91 & 7.97 & 4.22 \\
$\mathrm{~V}_{\text {вар. }}$ & 13 & 16 & 23 \\
\hline \multicolumn{4}{c}{ Олигоценовые отложения $(\mathrm{n}=3)$} \\
\hline $\mathrm{X}_{\text {ср. }}$ & 33.33 & 41.67 \\
$\sigma$ & 12.95 & 17.51 & 25 \\
$\mathrm{~V}_{\text {вар. }}$ & 39 & 42 & 5.77 \\
\hline \multicolumn{4}{c}{ Миоценовые отложения (n=4) } \\
\hline $\mathrm{X}_{\text {ср. }}$ & 25 & 48 \\
$\sigma$ & 5 & 17.85 & 23 \\
$\mathrm{~V}_{\text {вар. }}$ & 20 & 37.59 & 47.24 \\
\hline
\end{tabular}

Примечание. $X_{\text {ср. }}$ - среднее значение содержания, \%; $\sigma$ - стандартное отклонение; $\mathrm{V}_{\text {вар. }}$ - коэффициент вариации, \%; n - количество образцов. Note. $\mathrm{X}_{\text {ср. }}$ - average concentration, $\%$; $\sigma$ - standard deviation; $\mathrm{V}_{\text {вар. }}$ - coefficient of variation, $\% ; \mathrm{n}$ - number of samples. (a)

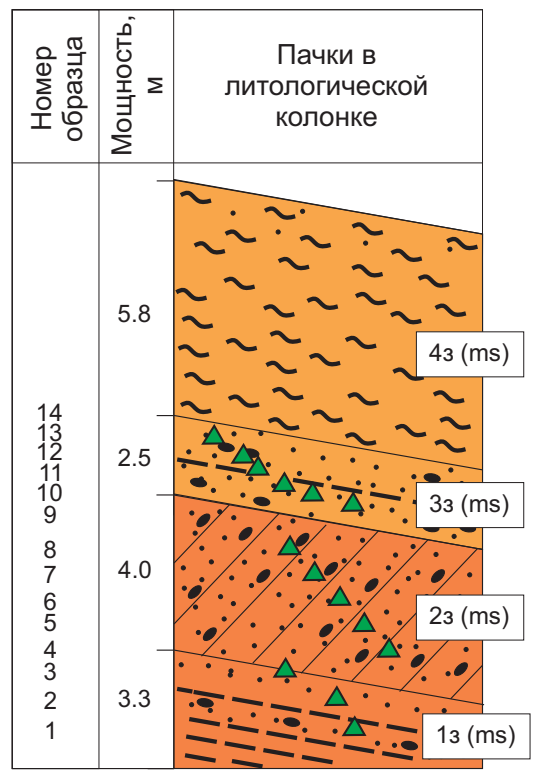

(б)

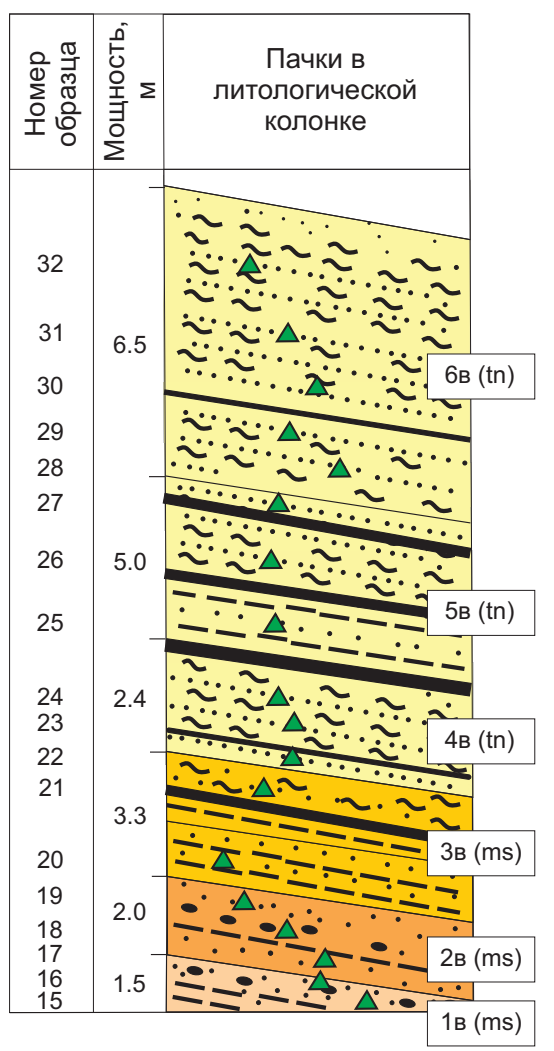

Рис. 5. Схема отбора образцов на гранулометрический анализ осадочных отложений западной (a) и восточной (б) части северной расчистки. Усл. обозн. см. рис. 2.

Fig. 5. Sampling scheme for particle size analysis of the sediments from the western ( $a$ ) and eastern (б) parts of the northern outcrop. See Fig. 2 for the legend. 
поверхностными скоростями течения 0.3-0.4 м/с, уклонами водного зеркала 0.1-0.2 м/км, меженными глубинами 0.5-1.7 м и шириной русел 15-92 м.

За счет увеличения размерности частиц средняя по крупности часть песчаного спектра характеризуется ухудшением сортировки - от недостаточной до плохой ( $\sigma=0.49-1.26)$, устойчивым плюсовым коэффициентом асимметрии и низкими положительными значениями эксцесса. Последнее обстоятельство определяет усиление процессов тектогенеза. Слабоподвижный характер ( $\phi$-критерий менее 100 единиц) палеоводотоков по числу Фруда был присущ полугорному (Fr=0.1-0.3) типу стабильных, хорошо оформленных русел с водосборной площадью >100 км² и свободным течением воды в обычном и благоприятном положении ложа $(\mathrm{n}=33.0-36.5)$.

В крупных песчаных разностях сортировка отсутствует ( $\sigma=1.37-1.76)$, что свидетельствует о недалеком переносе водным потоком, обладавшим повышенным энергетическим потенциалом, способным обрабатывать грубозернистую часть ЭПР (эмпирический полигон распределения) в достаточно хорошей степени при слабоустойчивом тектоническом фоне. Накопление осадков осуществлялось мобильными потоками полугорного типа в благоприятных условиях состояния ложа (n=31.8-32.5). Имел место переходный и турбулентный режим осаждения, сальтационный перенос, а также донное волочение, что обосновывается значениями универсального критерия Ляпина ( $\beta>0.5)$, указывающими на образование мелкогрядовых подвижных форм руслового рельефа (наличие наклонно- и косослоистых текстур в разрезе).

Псефитово-псаммитовые смеси обладают максимальными значениями седиментационных характеристик - полным отсутствием сортировки ( $\sigma=1.96-2.24)$, высоким динамизмом и нестабильным протеканием эндогенных процессов. Палеоводотокам был присущ горно-грядовый с развитыми подвижными формами донного рельефа тип русел преимущественно средних рек (ширина водотока 120-132 м) с правильным хорошо разработанным галечным ложем в нижнем течении.

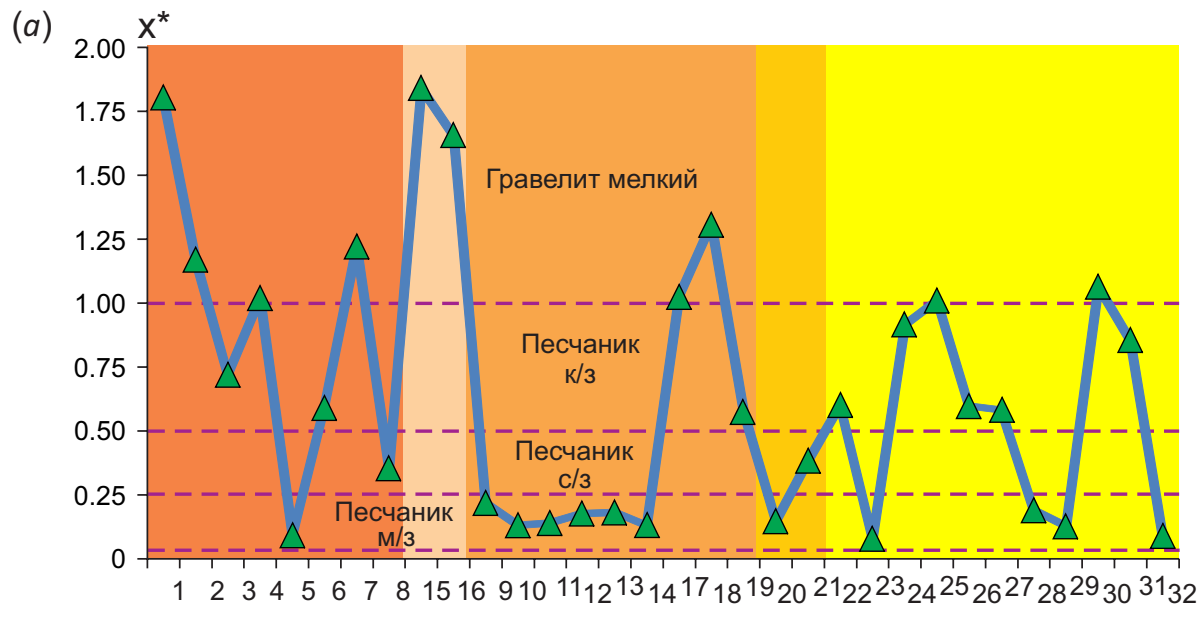

(б)

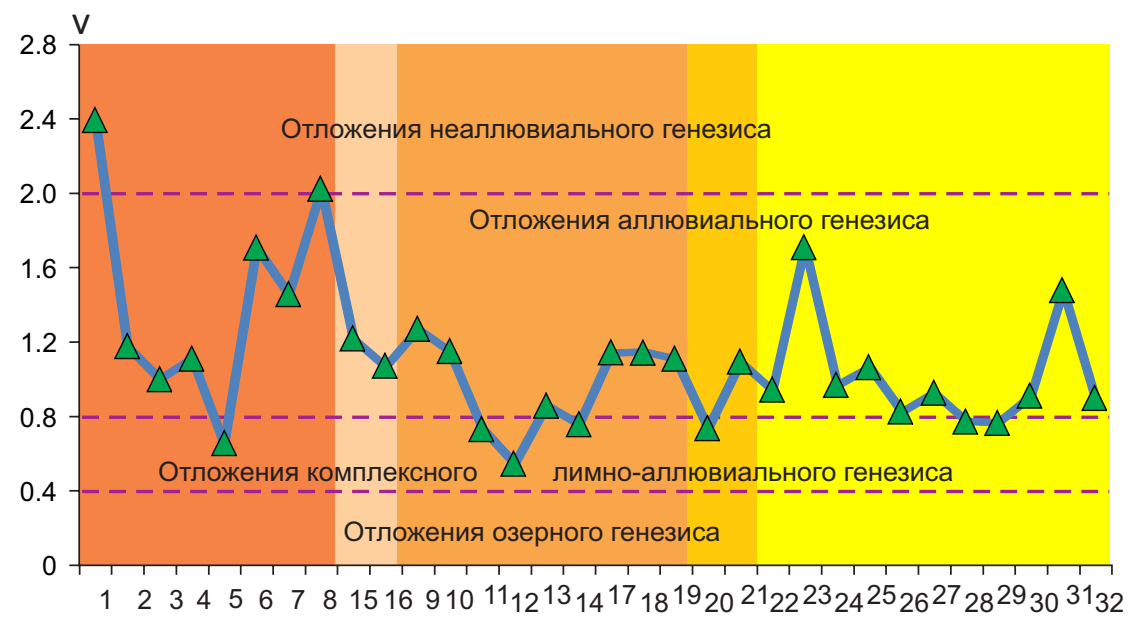

Рис. 6. Сопоставление средневзвешенного диаметра частиц $\mathrm{x}^{*}(a)$, коэффициента вариации $v($ ().

Слои западной и восточной части северной расчистки Мишихинского разреза представлены в единой возрастной последовательности, реконструированной по палинологическим данным. Условные обозначения см. рис. 2 и 5.

Fig. 6. Comparison of weighted average particle diameter $\mathrm{x}^{*}(a)$, and coefficient of variation $v$ (б).

The layers of the western and eastern parts of the northern outcrop (Mishikha section) are presented in a common age sequence reconstructed from the palynological data. See Figs. 2 and 5 for the legend. 
Генетико-фациальная природа этих осадков сопоставляется с аллювиальными русловыми грядовыми песками речной макрофации.

\section{6. МИНЕРАЛЬНЫЙ СОСТАВ ОТЛОЖЕНИЙ}

Соотношения минералов, определенные рентгенофазовым анализом в разновозрастных отложениях северной расчистки Мишихинского разреза, приведены в табл. 2.

В отложениях эоцена преобладает терригенная фракция полевых шпатов (среднее четырех определений $51 \%$ при малом содержании глинистых минералов (10-20 \%), представленных гидрослюдой, смектитом и каолинитом (рис. 7, а). Отложения олигоцена отличаются разнородным распределением минералов терригенной фракции (коэффициенты вариации 39-42 \%) и полиминеральным составом глинистой фракции: каолинит, гидрослюда, смектит и хлорит. Отложения миоцена содержат повышенное количество полевых шпатов (48 \%) и минимальное - кварца (25 \%). Полиминеральный состав глинистой фракции практически идентичен олигоценовым отложениям (каолинит, гидрослюда, смектит и хлорит) (рис. 7, б). Отложения верхнего миоцена - нижнего плиоцена отличаются меньшим количеством терригенной фракции (55 \%) и существенным содержанием глинистых минералов (45 \%), представленных гидрослюдой, смектитом и каолинитом (рис. 7, в).

\section{7. ЛИТОГЕОХИМИЯ}

В факторном анализе пород аллювия с прослоями углей группирование образцов по петрогенным оксидам несколько затушевывается литогеохимическим контрастом между обломочной составляющей песчаников и алевропесчаников с одной стороны и глин с детритом - с другой. Этот контраст реализуется в двух первых факторах: F1 - 43.1 \% и F2 - 21.3 \% (рис. 8, а, б).

По первому фактору разделяются оксиды, входящие в состав глин и органического детрита (ППП, $\mathrm{Al}_{2} \mathrm{O}_{3}$ ), а также коры выветривания $\left(\mathrm{Fe}_{2} \mathrm{O}_{3}, \mathrm{TiO}_{2}, \mathrm{FeO}, \mathrm{MnO}\right)$ по отношению к оксидам песчаников и алевропесчаников $\left(\mathrm{SiO}_{2}, \mathrm{Na}_{2} \mathrm{O}, \mathrm{K}_{2} \mathrm{O}, \mathrm{CaO}\right)$. По второму фактору разделяется совокупность компонентов глин с детритом и компонентов коры выветривания (обр. 26).

В группе терригенных пород определены интервалы содержаний $\mathrm{SiO}_{2}=57.0-69.6$ мас. \%, $\mathrm{K}_{2} \mathrm{O}=1.5-4.1$ мас. \%, $\mathrm{Na}_{2} \mathrm{O}=1.90-3.19$ мас. \% с интервалами ППП (потери при прокаливании) = 3.3-9.9 мас. \% и $\mathrm{Al}_{2} \mathrm{O}_{3}=15.6-19.0$ мас. \%. Для группы глин с детритом показательны интервалы ППП=7.8-35.9 мас. \% и $\mathrm{Al}_{2} \mathrm{O}_{3}=19.1-24.4$ мас. \%. Кора выветривания (обр. 26) отличается высокой окисленностью железа $\left(\mathrm{Fe}_{2} \mathrm{O}_{3} / \mathrm{FeO}=16.9\right)$ при содержании ППП= 10.4 мас. $\%, \mathrm{Al}_{2} \mathrm{O}_{3}=17.9$ мас. $\%, \mathrm{SiO}_{2}=42.2$ мас. $\%, \mathrm{~K}_{2} \mathrm{O}=$ 2.1 мас. $\%$ и $\mathrm{Na}_{2} \mathrm{O}=0.8$ мас. $\%$.

На рис. 8, в, г, в факторном анализе используются только образцы тренда обломочного материала (группы 1 на панели а). Возрастное группирование от эоцена до квартера отчетливо выражено в распределении фигуративных полей в квадрантах I и III. Векторы образцов эоценовых отложений находятся в квадранте I, а олигоценовых - смещены в квадрант III. Векторы образцов нижнемиоценовых отложений вновь находятся в квадранте I в виде однородного изометричного поля. Векторы образцов среднемиоценовых и верхнемиоценовых - нижнеплиоценовых отложений разделяются на контрастные совокупности I и III квадрантов. К совокупности III квадранта относится песчаный наполнитель плейстоценовых галечников.

Таблица 2. Соотношение основных минералов отложений по данным рентгенофазового анализа

Table 2. Ratios of the main minerals, according to the X-ray phase analysis

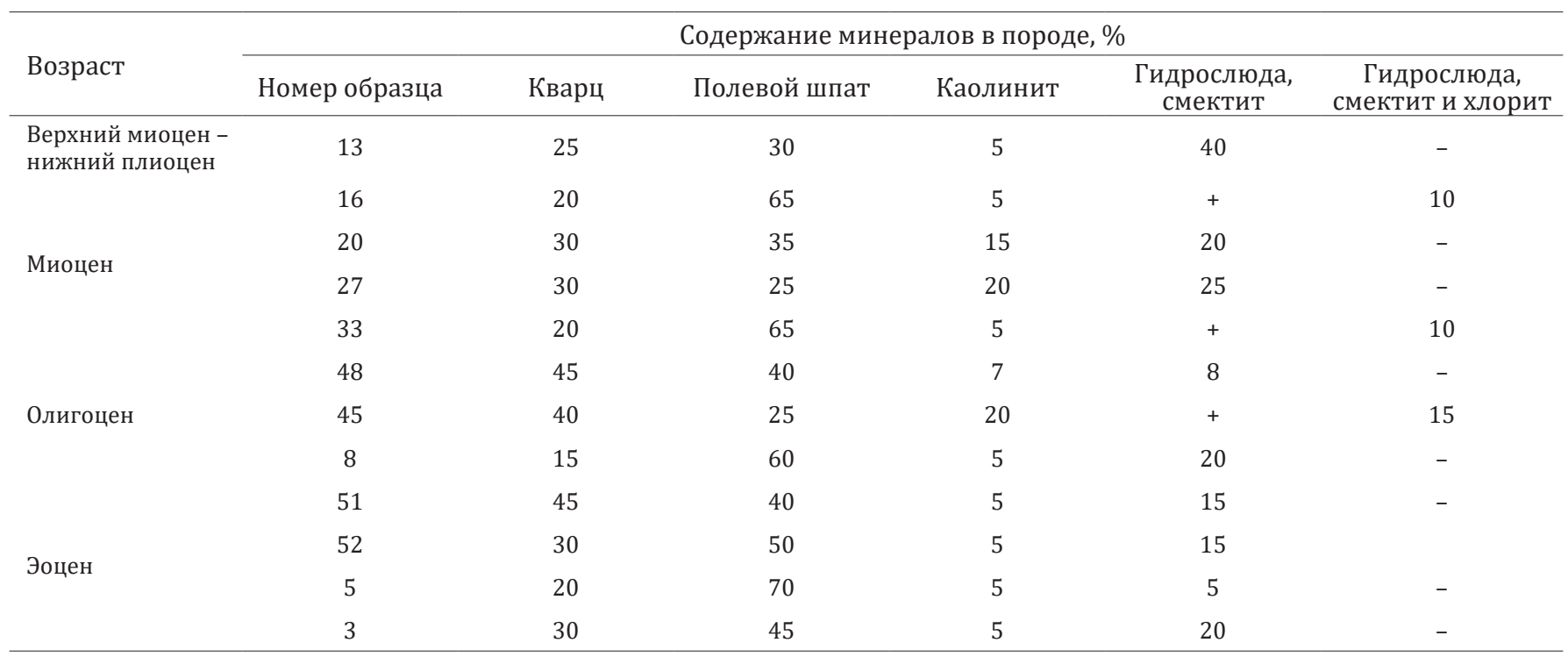

Примечание. Местоположение образцов см. на рис. 2.

Note. Sampling sites are shown in Fig. 2. 
(a)

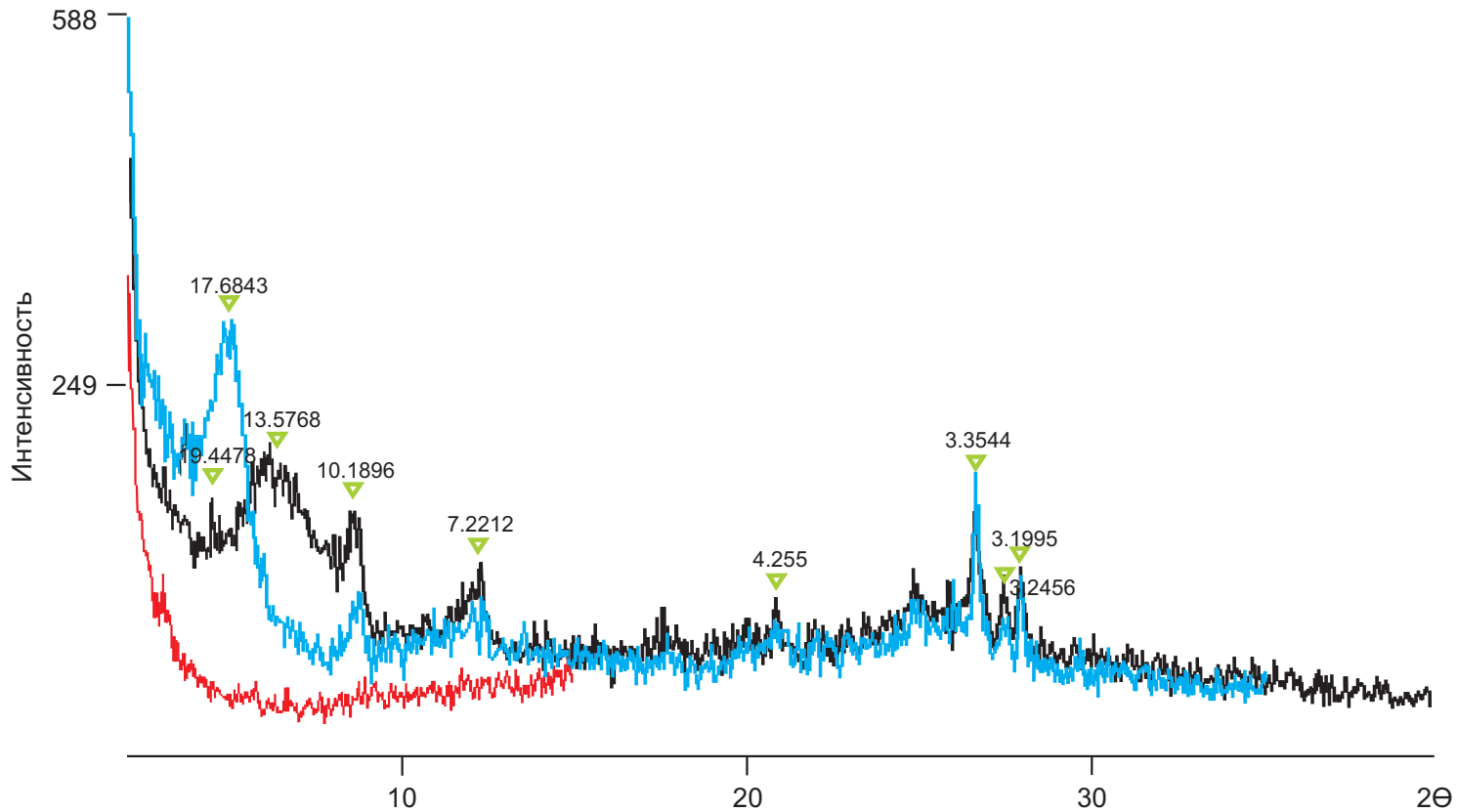

(б)

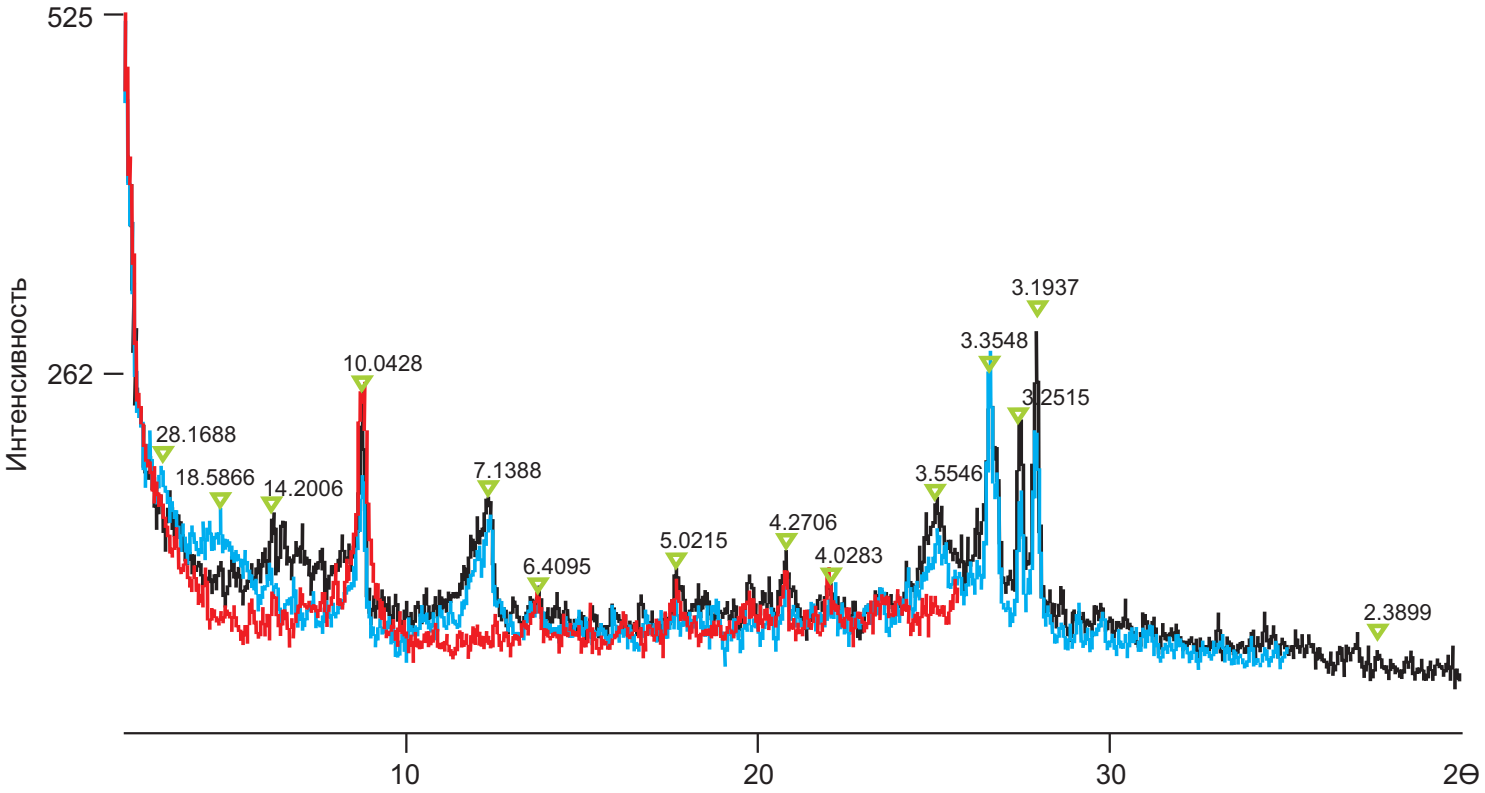

(в)

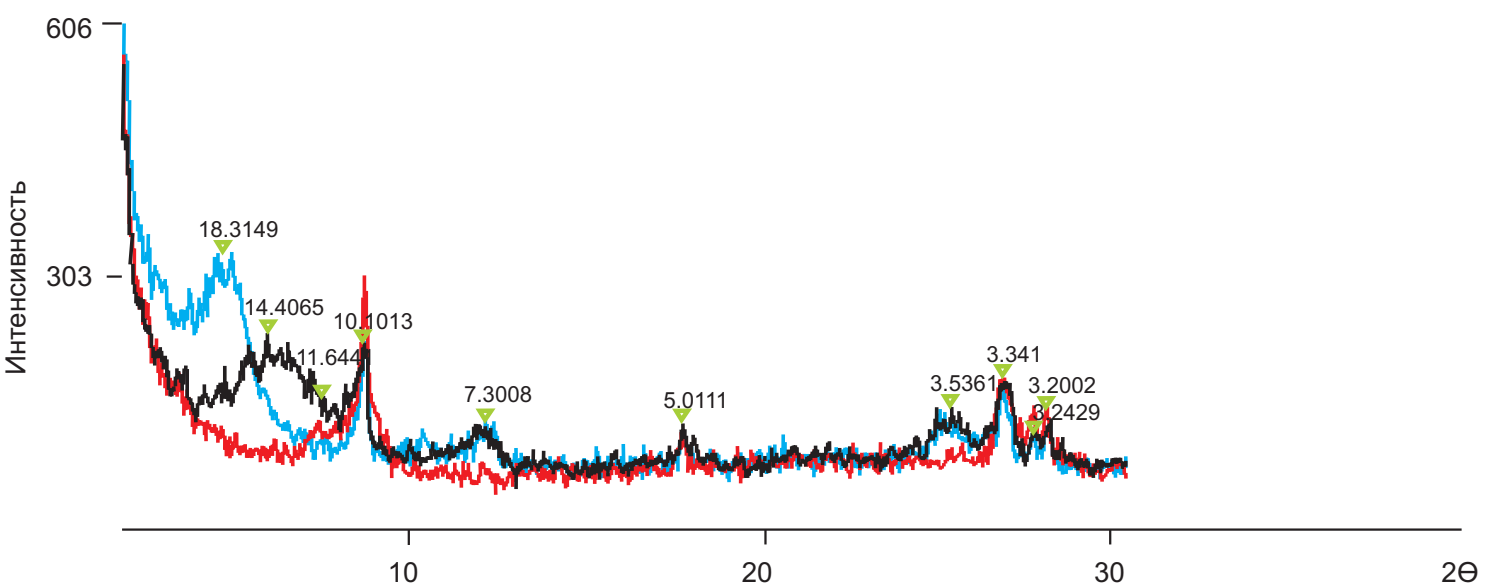

Рис. 7. Результаты рентгенофазового анализа глинистых минералов представительных образцов отложений: $(a)$ - эоцена (обр. 3), (б) - миоцена (обр. 33) и (в) - верхнего миоцена - нижнего плиоцена (обр. 13).

Fig. 7. Results of the X-ray phase analysis of clay minerals from the representative samples of the Eocene (sample 3, $a$ ), Miocene (sample 33, б) and Upper Miocene - Lower Pliocene (sample 13, в) sediments. 


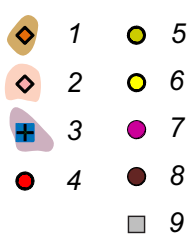

(б)

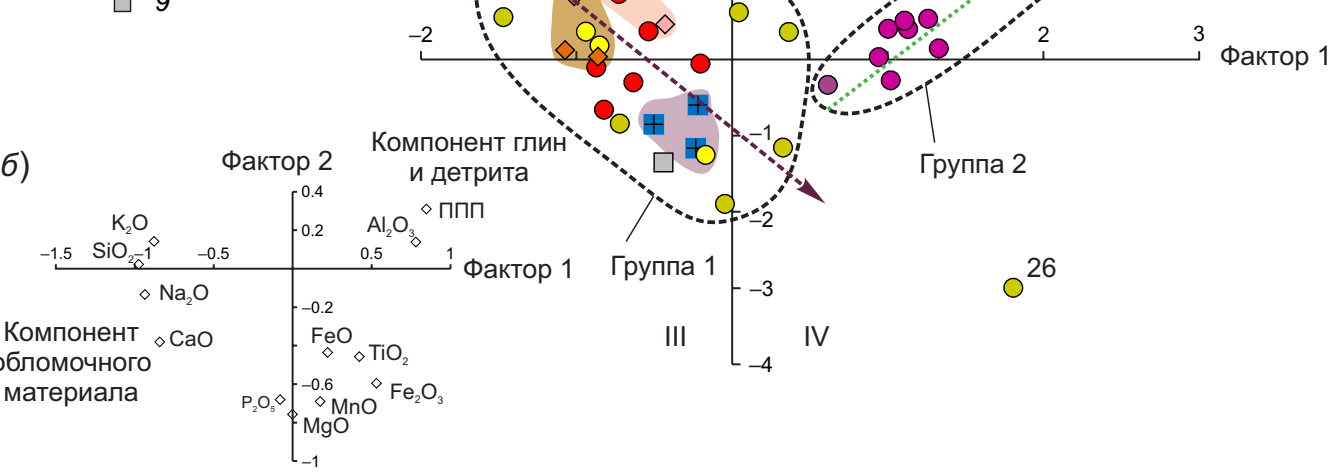

(2)

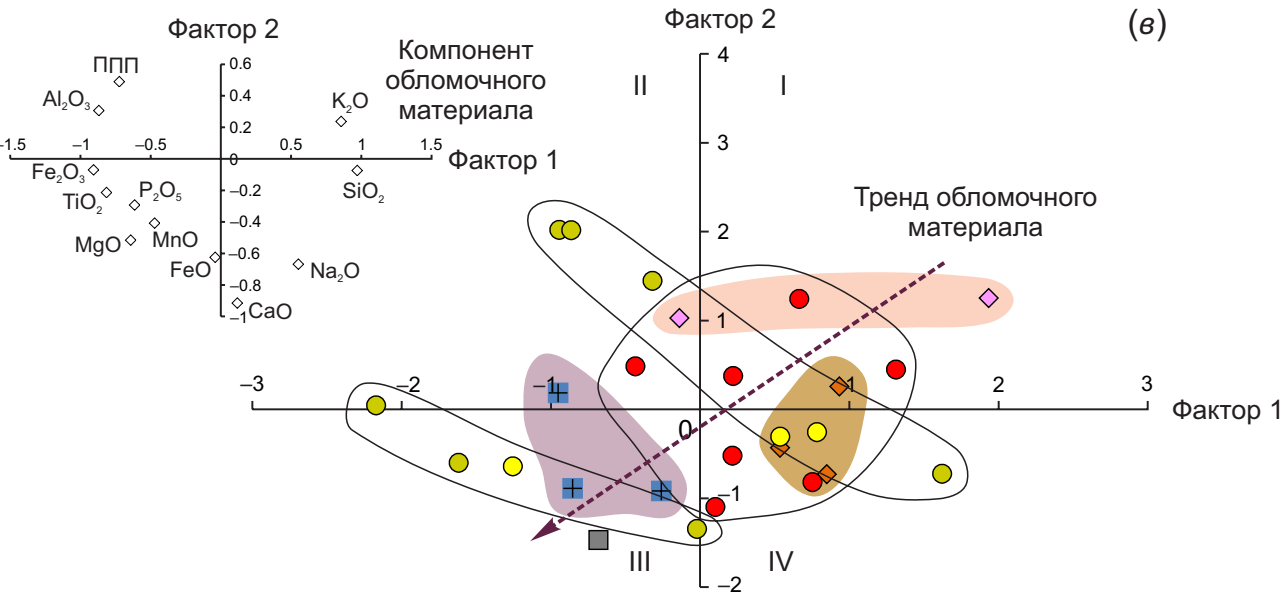

Рис. 8. Факторные диаграммы петрогенных оксидов.

(a) - диаграмма векторов образцов, (б) - диаграмма векторов переменных. Фактор 1: ППП $\Pi^{0.84}, \mathrm{Al}_{2} \mathrm{O}_{3}{ }^{0.78}, \mathrm{Fe}_{2} \mathrm{O}_{3}^{0.53}, \mathrm{TiO}_{2}^{0.42}, \mathrm{FeO}^{0.22}$; $\mathrm{MnO}^{0.17}, \mathrm{SiO}_{2}^{-0.97}, \mathrm{Na}_{2} \mathrm{O}^{-0.93}, \mathrm{~K}_{2} \mathrm{O}^{-0.87}, \mathrm{CaO}^{-0.84}, \mathrm{P}_{2} \mathrm{O}_{5}^{-0.07}, \mathrm{MgO}^{-0.01}$. Фактор 2: ППП ${ }^{0.31}, \mathrm{~K}_{2} \mathrm{O}^{0.14}, \mathrm{Al}_{2} \mathrm{O}_{3}{ }_{3}^{0.13}, \mathrm{SiO}_{2}{ }^{0.02}, \mathrm{MgO}^{-0.75} ; \mathrm{MnO}^{-0.69}, \mathrm{P}_{2} \mathrm{O}_{5}^{-0.68}$, $\mathrm{Fe}_{2} \mathrm{O}_{3}{ }^{-0.59}, \mathrm{TiO}_{2}^{-0.45}, \mathrm{FeO}^{-0.43} ; \mathrm{CaO}^{-0.38}, \mathrm{Na}_{2} \mathrm{O}^{-0.13} \cdot(\mathrm{s})$ - диаграмма векторов образцов группы 1 на панели $(a)$; ( 2$)$ - диаграмма векторов переменных группы 1 (вес компонентов представлен только графически).

Условные обозначения значков 1-6 см. на рис. 4. Дополнительные значки: 7 - глина нижнего - среднего миоцена, насыщенная детритовым материалом; 8 - бурый уголь этого же возраста; 9 - песчаник из четвертичной перекрывающей пачки.

Fig. 8. Factor diagrams of the major oxides.

(a) - diagram of sample vectors, (6) - diagram of vectors for variables. Factor $1: \Pi \Pi \Pi^{0.84}, \mathrm{Al}_{2} \mathrm{O}_{3}{ }^{0.78}, \mathrm{Fe}_{2} \mathrm{O}_{3}{ }^{0.53}, \mathrm{TiO}_{2}{ }^{0.42}, \mathrm{FeO}^{0.22} ; \mathrm{MnO}^{0.17}$, $\mathrm{SiO}_{2}{ }^{-0.97}, \mathrm{Na}_{2} \mathrm{O}^{-0.93}, \mathrm{~K}_{2} \mathrm{O}^{-0.87}, \mathrm{CaO}^{-0.84}, \mathrm{P}_{2} \mathrm{O}_{5}^{-0.07}, \mathrm{MgO}^{-0.01}$. Factor 2: $\Pi \Pi \Pi^{0.31}, \mathrm{~K}_{2} \mathrm{O}^{0.14}, \mathrm{Al}_{2} \mathrm{O}_{3}^{0.13}, \mathrm{SiO}_{2}{ }^{0.02}, \mathrm{MgO}^{-0.75} ; \mathrm{MnO}^{-0.69}, \mathrm{P}_{2} \mathrm{O}_{5}^{-0.68}, \mathrm{Fe}_{2} \mathrm{O}_{3}^{-0.59}, \mathrm{TiO}_{2}^{-0.45}$, $\mathrm{FeO}^{-0.43} ; \mathrm{CaO}^{-0.38}, \mathrm{Na}_{2} \mathrm{O}^{-0.13} \cdot(\mathrm{B})$ - diagram of sample vectors of group 1 from panel $(a)$; ( 2$)$ - diagram of vectors for variables of group 1 (component weights are presented only graphically).

See Fig. 4 for the legend. 7 - Lower - Middle Miocene clay, enriched with detrital material; 8 - Lower - Middle Miocene brown coal; 9 - sandstone from a Quaternary overlapping unit.

\section{8. ОБСУЖДЕНИЕ}

\section{1. Место отложений Мишихинского разреза} на Танхойской тектонической ступени

По характеру осадочных комплексов Танхойская тектоническая ступень разделяется на западный (Осиновский), центральный (Танхойский) и восточный (Мишихинско-Клюевский) блоки [Rasskazov et al., 2014]. В западном блоке залегает аллювиальный комплекс Осиновской палеодолины - осиновская и аносовская свиты миоцена, плиоцена и нижнего плейстоцена. В центральном блоке представлены отложения танхойской болотно-старичной фации - танхойская свита миоцена - нижнего плиоцена. В восточном блоке находятся аллювиальные отложения Мишихинско-Клюевской палеодолины.

Эоценовый аллювий в основании толщи Мишихинско-Клюевской палеодолины вместе с аллювиальными отложениями олигоцена относится к мишихинской толще. Вышележащая миоцен-нижнеплиоценовая часть разреза соответствует по возрасту танхойской свите. Мы предполагаем, что древний эоцен-олигоценовый аллювий, включающий горизонт «синих глин», 
образовался в результате размыва шовной зоны милонитов на Южно-Байкальском палеогеновом поднятии, а более молодой аллювий накапливался вследствие размыва постпалеогенового поднятия Хамар-Дабана [Al Hamoud et al., 2019].

Вдоль Танхойской тектонической ступени начало седиментации последовательно смещалось с востока на запад. Наиболее ранний аллювий накапливался в эоцене в Мишихинско-Клюевском блоке. В позднем олигоцене «синие глины» ложились в основание осадочной толщи в Танхойском блоке, и, наконец, в миоцене осиновский аллювий распространялся в Осиновском блоке. Накопление отложений аносовской свиты верхнего плиоцена - нижнего плейстоцена в Осиновском блоке при отсутствии отложений этого возраста в двух других блоках свидетельствует о контрастных движениях Мишихинско-Клюевского и Танхойского блоков с одной стороны и Осиновского блока - с другой, сложившихся в процессе тектонической эволюции к плиоцену - раннему плейстоцену.

Осадочные слои Танхойского и Мишихинско-Клюевского блоков испытывали различные деформации. В Танхойском блоке слои наклонены под углом 20-45 преимущественно с юга на север, от Хамар-Дабана к Байкалу. Такое падение выдерживается по всему блоку от пос. Танхой до долин рек Малая и Большая Язовка. Восточнее, в долине р. Мишиха, происходит заметный разворот падения слоев. В междуречье Мишиха - Болваниха, на территории от Байкала до склона Хамар-Дабана, слои падают к востоку под углом 5-20 [Rasskazov et al., 2014]. Таким же падением характеризуются слои изученной северной расчистки Мишихинского разреза. Поскольку разрез находится вблизи сопредельного Танхойского блока, опрокинутое залегание эоцен-нижнеплиоценовых слоев может рассматриваться как пограничная межблоковая деформационная аномалия.

\section{2. Корреляционное значение отложений Мишихинского разреза}

При разделении Танхойской ступени на три тектонических блока центральный (Танхойский) блок может рассматриваться в качестве структуры, разделяющей Мишихинско-Клюевский и Осиновский блоки. Соответственно в неотектонической эволюции Осиновского блока определяющую роль должны были играть деформации вдоль Юго-Западного бортового разлома ЮжноБайкальской впадины, а в неотектонической эволюции Мишихинско-Клюевского блока - деформации вдоль разлома, протягивающегося в дельту р. Селенги. Такое соотношение главных граничных разломов Южно-Байкальской впадины допускалось Н.А. Флоренсовым [Florensov, 1968].

По представлениям Н.А. Логачева [Logatchev, 1974, 2003], Байкальская рифтовая зона могла развиваться от Южно-Байкальской впадины начиная с палеоцена. Это предположение основывалось на вероятном залегании палеоценовых слоев ниже эоцен-олигоценовой части разреза, вскрытой скважиной в дельте р. Селенги на глубинах 2550-3100 м [Zamaraev, Samsonov, 1959; Logatchev, 1974]. В береговых обнажениях и скважинах Южного Байкала палеоценовые отложения до сих пор не были известны, хотя пограничные слои мела - палеогена широко распространены на обоих флангах рифтовой зоны, в Селенгино-Витимском и Предбайкальском прогибах [Logatchev et al., 1964; Logatchev, 1974; Pavlov et al., 1976].

В Селенгино-Витимском прогибе мохейская свита кампана - маастрихта надстраивается нижней и верхней подсвитами иренгинской свиты соответственно палеоцена - эоцена и среднего - верхнего эоцена. Эти стратоны залегают в разрезах со стратиграфическим несогласием. После общего кампан-маастрихтского запуска седиментации в Селенгино-Витимском прогибе в той или иной степени проявились структурные перестройки, в которых отразилась индивидуальность сначала палеоцен-эоценового, а затем - средневерхнеэоценового стратона [Rasskazov et al., 2007; Chuvashova et al., 2019].

Антецедентный прорыв р. Селенги образовался между воздымающимися хребтами Хамар-Дабан и УланБургасы только в конце плиоцена - начале плейстоцена [Logatchev, 1974]. Верхнеплиоценовый - плейстоценовый аллювий р. Селенги трансгрессивно перекрыл эоценплиоценовую толщу, полого наклоненную к северо-западу. Такое же перекрытие со структурно-стратиграфическим несогласием перекрывающей плейстоценовой пачки и подстилающей наклоненной эоцен-нижнеплиоценовой толщи наблюдается в Мишихинском разрезе (см. рис. 2).

Эоцен-олигоценовые отложения нижней части разреза Мишихинско-Клюевской палеодолины в совокупности с вышележащей миоцен-нижнеплиоценовой танхойской свитой свидетельствуют о накоплении аллювия на протяжении не менее 30 млн лет. В Мишихинском разрезе представлен аллювий, одновозрастный с седиментационным осадочным комплексом дельты р. Селенги, в котором мощные (несколько сотен метров) алевритовые (озерные и/или болотно-старичные) пачки эоцена - олигоцена, нижнего миоцена и плиоцена сменялись песчано-гравийными и песчаными аллювиальными пачками олигоцена - нижнего миоцена и среднего - верхнего миоцена. Несмотря на малую мощность стратонов Мишихинско-Клюевской палеодолины, не вызывает сомнений сходство строения ее разреза и разреза дельты р. Селенги, свидетельствующее о единой доплейстоценовой тектонической эволюции территории восточной и центральной части Танхойской тектонической ступени и южного борта центральной части Южно-Байкальской впадины.

\section{3. Деформации с опрокидыванием слоев - переход от раннеорогенного к позднеорогенному этапу развития рельефа}

Наиболее значительная плиоценовая структурная перестройка в Байкальской рифтовой зоне предполагалась исходя из смены в разрезах ее осевых впадин 


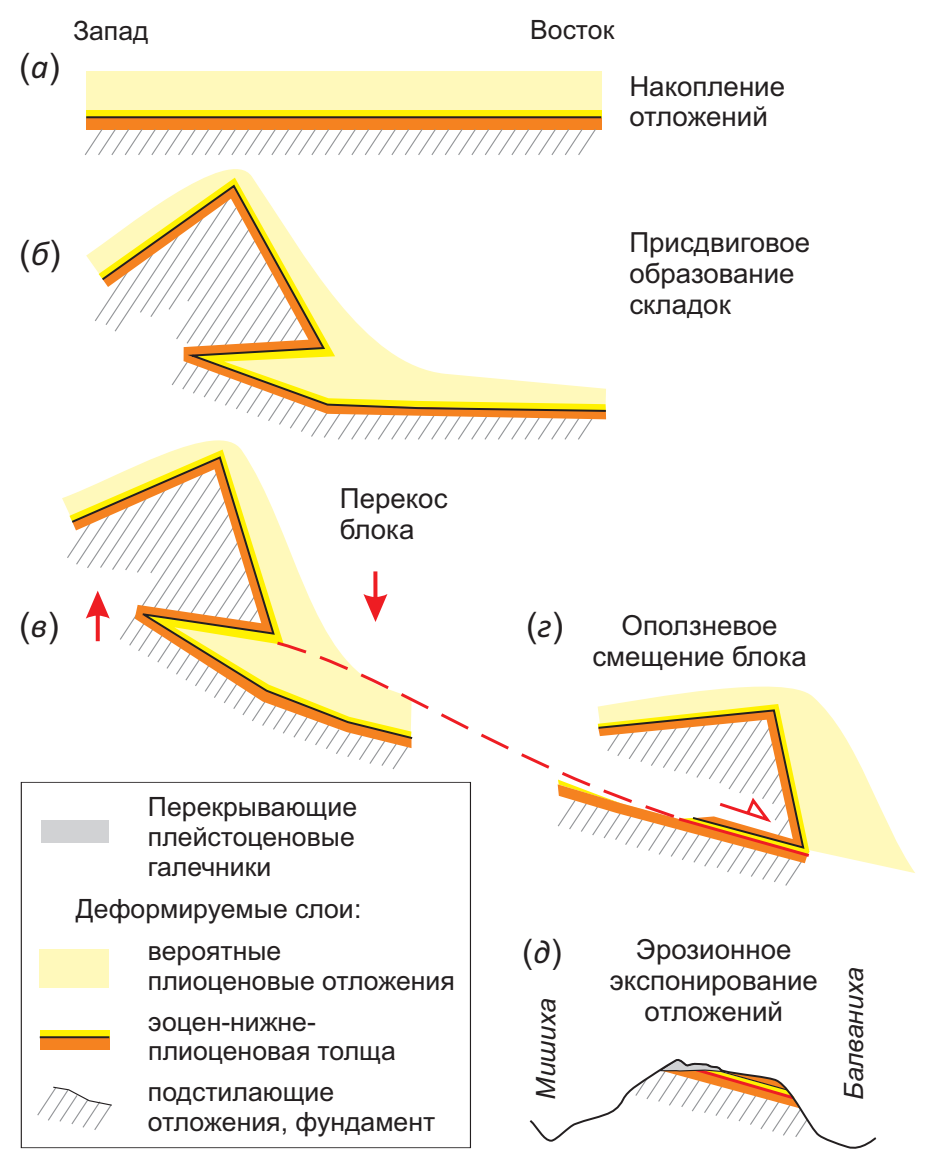

Рис. 9. Схематичная реконструкция последовательности событий, реализовавшихся в опрокинутом залегании слоев. События: $(a)$ - экзогенные, седиментационные; $(6,8)$ - эндогенные, тектонические; $(2, \partial)$ - экзогенные. На стадиях (2-д) рельеф преобразуется в борту тектонического озера.

Fig. 9. Schematic reconstruction of the events evidenced by the overturned bedding.

Events: $(a)$ - exogenous, sedimentary; $(\sigma, 8)$ - endogenous, tectonic; $(2, \partial)$ - exogenous. At stages $(2, \partial)$, relief transformations occurred at the coast of a tectonic lake.

тонкообломочных осадочных отложений угленосной танхойской свиты грубообломочными отложениями охристой аносовской свиты. Накопление танхойской свиты связывалось с медленными раннеорогенными (добайкальскими) неотектоническими движениями, а аносовской свиты - с быстрыми позднеорогенными (новобайкальскими) движениями [Logatchev, 1974]. В Мишихинском и Усть-Селенгинском разрезах переход от раннеорогенного этапа к позднеорогенному обозначился в резком структурном несогласии перекрывающих четвертичных толщ с нижележащими наклоненными эоцен-нижнеплиоценовыми толщами.

В Мишихинском разрезе вскрыт контакт опрокинутой толщи, смещавшейся по нижнеплиоценовому слою, находившемуся в пластичном (жидком) состоянии на хрупкой подложке нормально залегающей эоцен-олигоценовой осадочной толщи (см. рис. 2). Для объяснения обратного залегания эоцен-нижнеплиоценовых слоев предлагается сценарий деформаций, включающий эндогенную и экзогенную составляющие (рис. 9). После накопления осадочной толщи эоцена - начала плиоцена в спокойных тектонических условиях (рис. 9, а) в плиоцене активизируются сдвиговые смещения по субширотному разлому, сопровождающиеся образованием лежачей складки второго порядка, в верхнем крыле которой древние слои находятся выше молодых слоев (рис. 9, б). В результате более позднего перекоса блока (рис. 9, в) реализуются оползневые движения опрокинутых эоцен-нижнеплиоценовых слоев до параллельного совмещения с более жесткой подложкой эоцен-верхнеолигоценовых слоев (рис. 9, г). Сочетание толщ с нормальным и опрокинутым залеганием экспонируется в эрозионном рельефе на водоразделе Мишиха - Балваниха (рис. 9, д).

\section{9. ЗАКЛЮЧЕНИЕ}

В Байкальской рифтой зоне, в Мишихинском разрезе южного берега Байкала, впервые обнаружены и изучены осадочные слои широкого (эоцен-нижнеплиоценового) возрастного диапазона. Результаты гранулометрического анализа, рентгенофазового анализа минерального состава и литогеохимические данные свидетельствуют об аллювиальном происхождении стратонов с участием болотно-старичных фаций.

Возраст отложений обоснован спорово-пыльцевыми спектрами, которые отнесены к трем палинозонам: 
I - эоцена - олигоцена, II - раннего - среднего миоцена (подзона а - в нижней части Tsuga, Picea, в верхней части Quercus, Taxodiaceae, Momipites, Carya и подзона bFagus, Quercus, Tsuga) и III - позднего миоцена - начала плиоцена (подзона v - Ulmus, Juglans, Carya и подзона g-Carya, Alnus).

В разрезе выявлено нормальное и опрокинутое залегание слоев, перекрытых с размывом чехлом плейстоценовых галечников. Эоцен-олигоценовая толща с нормальным залеганием находится в тектоническом контакте с опрокинутой эоцен-нижнеплиоценовой толщей. Деформации реализовались в опрокинутом залегании слоев на позднеорогенном этапе развития структуры Байкальской рифтовой зоны, во время образования глубокого Байкала. Нижний предельный возраст деформаций определен по слою, включающему наиболее молодой спорово-пыльцевой спектр начала плиоцена.

Аллювий отлагался в Мишихинско-Клюевской и Осиновской палеодолинах, на восточном и западном окончании Танхойской тектонической ступени, в центральной части которой (Танхойский блок) накопилась и выведена на поверхность мощная нижнемиоценовая болотно-старичная толща, наклоненная от Хамар-Дабана к Байкалу. В основании осадочной толщи Танхойского блока находится верхнеолигоценовая пачка «синих глин». Разрез Мишихинско-Клюевского аллювия в целом коррелируется с разрезом отложений, вскрытых скважинами в дельте р. Селенги, в котором песчано-гравийные и песчаные аллювиальные пачки олигоцена - нижнего миоцена и среднего - верхнего миоцена чередовались с мощными алевритовыми (озерными и/или болотно-старичными) пачками эоцена - олигоцена, нижнего миоцена и плиоцена. Подобно слоям изученного Мишихинского разреза, слои Усть-Селенгинского разреза наклонены и с размывом перекрыты отложениями верхнего плиоцена - плейстоцена.

\section{0. БЛАГОДАРНОСТИ И ВКЛАД АВТОРОВ}

Обнажение документировалось В.Л. Коломийцем и Р.Ц. Будаевым с его дополнительным посещением С.В. Рассказовым, А. Аль Хамудом и А. Хассаном. Общая обработка и анализ полученных данных с подготовкой текста статьи проводились А. Аль Хамудом, С.В. Рассказовым, И.С. Чувашовой и В.Л. Коломийцем. Гранулометрический анализ отложений выполнялся В.Л. Коломийцем, А. Аль Хамудом и А. Хассаном. Палинологический анализ осуществлялся Т.Ф. Трегуб и М.А. Волковым. Рентгенофазовый анализ выполнялся М.Н. Рубцовой с использованием рентгеновского дифрактометра ДРОН-3.0 ЦКП «Геодинамика и геохронология» ИЗКСОРАН. Авторы благодарят химиков-аналитиков Г.В. Бондареву, Н.Н. Ухову и М.М. Самойленко за выполненные силикатные анализы и двух анонимных рецензентов за комментарии, способствовавшие улучшению статьи.

\section{1. ЛИТЕРАТУРА/REFERENCES}

Al Hamoud A., Rasskazov S.V., Chuvashova I.S., Tregub T.F., Volkov M.A., Kulagina N.V., Kolomiets V.L., Budaev R.T., 2019.
Temporal Compositional Variations of Cenozoic Sediments on the Tankhoi Tectonic Step, the Southern Baikal. The Bulletin of Irkutsk State University, Earth Sciences Series 30, 108-129 (in Russian) [Аль Хамуд А., Рассказов С.В., Чувашова И.С., Трегуб Т.Ф., Волков М.А., Кулагина Н.В., Коломиец В.Л., Будаев Р.Ц. Временные вариации состава кайнозойских отложений на Танхойской тектонической ступени Южного Байкала // Известия ИГУ. Серия Науки о Земле. 2019. Т. 30. С. 108-129]. https://doi.org/ 10.26516/2073-3402.2019.30.108.

Bolotnikova M.D., 1979. Spore-Pollen Complexes of Tertiary Deposits of the Western Coast of the Sea of Japan. Nauka, Moscow, 194 p. (in Russian) [Болотникова М.Д. Споровопыльцевые комплексы третичных отложений западного побережья Японского моря. М.: Наука, 1979. 194 с.].

Brown G. (Ed.), 1965. The X-Ray Identification and Crystal Structures of Clay Minerals. Mir Publishing House, Moscow, 599 p. (in Russian) [Рентгеновские методы изучения и структуры глинистых минералов / Ред. Г. Браун. М: Издво «Мир», 1965. 599 с.].

Chuvashova I.S., Hassan A., Al Hamoud A., Kovalenko S.N., Rudneva N.A., Rasskazov S.V., 2019. From the Selenga-Vitim Downwarp to the Vitim Plateau: Cenozoic Sedimentation and Volcanism. The Bulletin of Irkutsk State University. Series Earth Sciences 27, 138-153 (in Russian) [Чувашова И.С., Хассан А., Аль Хамуд А., Коваленко С.Н., Руднева Н.А., Рассказов С.В. Переход от Селенгино-Витимского прогиба к Витимскому плоскогорью: кайнозойское осадконакопление и вулканизм // Известия ИГУ. Серия Науки о Земле. 2019. Т. 27. С. 138-153]. https://doi.org/10. 26516/2073-3402.2019.27.138.

Florensov N.A., 1968. Baikal Rift Zone and Some Problems of Its Study. In: Baikal Rift. Nauka, Moscow, 40-56 (in Russian) [Флоренсов Н.А. Байкальская рифтовая зона и некоторые задачи ее изучения // Байкальский рифт. М.: Наука, 1968. С. 40-56].

Hubbard C.R., Snyder R.L., 1988. RIR - Measurement and Use in Quantitative XRD. Cambridge University Press 3 (2), 74-77. https://doi.org/10.1017/S0885715600013257.

Kolomiets V.L., 1998. Reconstructions of Paleostream Parameters from Fossil Sediments. Bulletin of the Buryat University. Series 3: Geography, Geology 2, 92-100 (in Russian) [Коломиец В.Л. Реконструкции параметров палеопотоков по ископаемым осадкам // Вестник Бурятского университета. Серия 3: география, геология. 1998. № 2. C. 92-100].

Logatchev N.A., 1958. Cenozoic Continental Deposits in Basins of the Baikal Type. Bulletin of the USSR Academy of Sciences. Geological Series 4, 18-29 (in Russian) [Логачев Н.A. Кайнозойские континентальные отложения впадин байкальского типа // Известия АН СССР. Серия геологическая. 1958. № 4. С. 18-29].

Logatchev N.A., 1974. The Sayan-Baikal and Stanovoe Highlands. In: N.A. Florensov, Highlands of Pribaikalie and Transbaikalia. Nauka, Moscow, 16-162 (in Russian) [Логачев Н.А. Саяно Баукальское становое нагорье // Нагорья Прибайкалья и Забайкалья / Ред. Н.А. Флоренсов. М.: Наука, 1974. С. 16-162]. 
Logatchev N.A., 2003. History and Geodynamics of the Baikal Rift. Russian Geology and Geophysics 4 (5), 391406 (in Russian) [Логачев Н.А. История и геодинамика Байкальского рифта // Геология и геофизика. 2003. Т. 44. № 5. C. 391-406].

Logatchev N.A., Brandt I.S., Rasskazov S.V., Ivanov A.V., Brandt S.B., Konev A.A., Ilyasova A.M., 2002. K-Ar Dating of the Paleocene Weathering Crust in the Baikal Region. Doklady Earth Sciences 385A (6), 648-650.

Logatchev N.A., Lomonosova T.K., Klimanova V.M., 1964. Cenozoic Sediments of the Irkutsk Amphitheater. Nauka, Moscow, 195 p. (in Russian) [Логачев H.A., Ломоносова T.К., Климанова В.М. Кайнозойские отложения Иркутского амфитеатра. М.: Наука, 1964. 195 с.].

Mashchuk I.M., Akulov N.I., 2012. Oligocene Deposits of the Baikal Rift Valley. Russian Geology and Geophysics 53 (4), 356-366 https://doi.org/10.1016/j.rgg.2012.02.012.

Mats V.D., 1985. New Data on Stratigraphy of the Miocene and Pliocene Deposits in the Southern Baikal. In: Issues of Geology and Paleogeography of Siberia and the Far East. ISU Publishing House, Irkutsk, 36-53 (in Russian) [Мац В.Д. Новые данные по стратиграфии миоценовых и плиоценовых отложений на юге Байкала // Вопросы геологии и палеогеографии Сибири и Дальнего Востока. Иркутск: Изд-во ИГУ, 1985. С. 36-53].

Mats V.D., 2015. The Baikal Rift: Pliocene (Miocene) Quaternary Episode or Product of Extended Development since the Late Cretaceous under Various Tectonic Factors. A Review. Geodynamics \& Tectonophysics 6 (4), 467-489 (in Russian) [Мац В.Д. Байкальский рифт: плиоцен (миоцен) - четвертичный эпизод или продукт длительного развития с позднего мела под воздействием различных тектонических факторов. Обзор представлений // Геодинамика и тектонофизика. 2015. Т. 6. № 4. С. 467489]. https://doi.org/10.5800/GT-2015-6-4-0190.

Mats V.D., Ufimtsev G.F., Mandelbaum M.M., Alakshin A.M., Pospeev A.V., Shimaraev M.N., Khlystov O.M., 2001. The Cenozoic Baikal Rift Basin: Its Structure and Geological History. GEO, Novosibirsk, 252 p. (in Russian) [Мац В.Д., Уфимцев Г.Ф., Мандельбаум М.М., Алакшин А.М., Поспеев А.В., Шимараев М.Н., Хлыстов О.М. Кайнозой Байкальской рифтовой впадины: строение и геологическая история. Новосибирск: ГЕО, 2001. 252 с.].

Mazilov V.N., Lomonosova T.K., Klimanova V.M., Kashaeva G.M., Ershov R.I., Semenova G.O., 1972. Lithology of Tertiary
Sediments in Basins of the Southwestern Baikal Rift Zone. Nauka, Moscow, 120 p. (in Russian) [Мазилов B.Н., Ломоносова Т.К., Климанова В.М., Кашаева Г.М., Ершов Р.И., Семенова Г.О. Литология третичных отложений впадин юго-западной части Байкальской рифтовой зоны. Москва: Наука, 1972.120 с.]

Pavlov S.F., Kashik S.A., Lomonosova T.K., Klimanova V.M., 1976. Cenozoic Weathering Crusts and Sedimentary Formations of the Western Baikal Region. Nauka, Novosibirsk, 160 p. (in Russian) [Павлов С.Ф., Кашик С.А., Ломоносова Т.К., Климанова В.М. Кайнозойские коры выветривания и осадочные формации Западного Прибайкалья. Новосибирск: Наука, 1976. 160 с.].

Rasskazov S.V., Lyamina N.A., Chernyaeva G.P., Luzina I.V., Rudnev A.F., Rezanov I.N., 2007. Cenozoic Stratigraphy of the Vitim Plateau: Phenomenon of Long Rifting in the South of East Siberia. GEO, Novosibirsk, 193 p. (in Russian) [Pacсказов С.В., Лямина Н.А., Черняева Г.П., Лузина И.В., Руднев А.Ф., Резанов И.Н. Стратиграфия кайнозоя Витимского плоскогорья: феномен длительного рифтогенеза на юге Восточной Сибири. Новосибирск: ГЕО, 2007. 193 c.].

Rasskazov S.V., Lyamina N.A., Luzina I.V., Chernyaeva G.P., Chuvashova I.S., Usol'tseva M.V., 2014. Sediments in the Tertiary Tankhoi Field, South Baikal Basin: Stratigraphy, Correlation and Structural Transformations in the Baikal Region. Geodynamics \& Tectonophysics 5 (4), 993-1032 (in Russian) [Рассказов С.В., Лямина Н.А., Лузина И.В., Черняева Г.П., Чувашова И.С., Усольцева М.В. Отложения Танхойского третичного поля, Южно-Байкальская впадина: стратиграфия, корреляции и структурные перестройки в Байкальском регионе // Geodynamics \& Tectonophysics. 2014. T. 5. № 4. C. 993-1032]. https://doi.org/ 10.5800/GT-2014-5-4-0165.

Tomskaya A.I., 1981. Cenozoic Palynology of Yakutia. Nauka, Novosibirsk, 221 p. (in Russian) [Томская А.И. Палинология кайнозоя Якутии. Новосибирск: Наука, 1981. 221 c.].

Zamaraev S.M., Samsonov V.V., 1959. Geology and Petroleum Potential of the Selenga Depression. In: Geology and Petroleum Potential of East Siberia. Gostoptekhizdat, Moscow, 456-474 (in Russian) [Замараев C.M., Самсонов B.B. Геологическое строение и нефтегазоносность Селенгинской депрессии // Геология и нефтегазоносность Восточной Сибири. М.: Гостоптехиздат, 1959. С. 456-474]. 